Illinois State University

ISU ReD: Research and eData

Theses and Dissertations

$10-10-2014$

\title{
Saleswomen And The Middle -Class: Gender And Class Conflict Within The Chicago Department Store, 1880-1930
}

Laura Wiggers

Illinois State University, Iwiggers@wacohi.net

Follow this and additional works at: https://ir.library.illinoisstate.edu/etd

Part of the History Commons

\section{Recommended Citation}

Wiggers, Laura, "Saleswomen And The Middle -Class: Gender And Class Conflict Within The Chicago Department Store, 1880-1930" (2014). Theses and Dissertations. 269.

https://ir.library.illinoisstate.edu/etd/269

This Thesis is brought to you for free and open access by ISU ReD: Research and eData. It has been accepted for inclusion in Theses and Dissertations by an authorized administrator of ISU ReD: Research and eData. For more information, please contact ISUReD@ilstu.edu. 


\section{SALESWOMEN AND THE MIDDLE-CLASS: GENDER AND CLASS CONFLICT WITHIN THE CHICAGO DEPARTMENT STORE,}

$1880-1930$

\section{Laura N. Wiggers}

125 Pages

December 2014

Between 1880 and 1930, the emergence of a consumer culture and the increase in wage-earning women challenged traditional values. Anxiety over these changes was perhaps strongest within the middle-class who developed a reform culture to respond to a society that they felt was in chaos. As monuments of consumption, department stores sat at the nexus of the working-class culture of saleswomen and the middle-class culture of customers and management. A national leader in both the creation of the modern department store and the Progressive reform movement, Chicago provides a unique location to study this intersection. Middle-class reformers and female clerks alike were concerned with low pay and poor working conditions, but middle-class reformers also acted out of concern for the clerks' moral behavior and well-being, while saleswomen were largely frustrated by limited economic opportunities and a lack of autonomy. It was ultimately the combined efforts of store clerks, reformers, and wider social changes that led to gradual, but significant improvement in working conditions for saleswomen by the end of the 1920s. 
SALESWOMEN AND THE MIDDLE-CLASS: GENDER AND CLASS

CONFLICT WITHIN THE CHICAGO DEPARTMENT STORE,

$1880-1930$

LAURA N. WIGGERS

A Thesis Submitted in Partial

Fulfillment of the Requirements

for the Degree of

MASTER OF SCIENCE

Department of History

ILLINOIS STATE UNIVERSITY

2014 
(C) 2014 Laura N. Wiggers 
SALESWOMEN AND THE MIDDLE-CLASS: GENDER AND CLASS

CONFLICT WITHIN THE CHICAGO DEPARTMENT STORE,

$1880-1930$

LAURA N. WIGGERS

COMMITTEE MEMBERS:

Amy L. Wood, Chair

Kyle E. Ciani 


\section{CONTENTS}

$\begin{array}{ll}\text { CONTENTS } & \text { i }\end{array}$

\section{CHAPTER}

I. INTRODUCTION 1

Historiography $\quad 7$

Use of Primary Sources and Chapter Overview 10

II. GROWTH OF CONSUMERISM 12

Changes in American Business and Consumer Behavior 12

Consumerism and Social Class 20

Encouraging Consumerism 24

Women as Consumers $\quad 29$

III. CONFLICTING VALUES, THE DEPARTMENT STORE, AND ITS SALESWOMEN

Women in Public and Increased Labor Participation 36

Rise of the Female Clerk $\quad 47$

Department Store Reflects the Middle-Class 51

Middle-Class Managers $\quad 56$

Customer Interactions $\quad 63$

Middle-Class Views of Saleswomen $\quad 67$

IV. MIDDLE-CLASS REFORMERS AND THEIR IMPACT 72

Origins of the Reform Movement $\quad 72$

Motivations of Reformers $\quad 79$

Efforts of Reformers $\quad 81$

Role of the Labor Movement $\quad 88$

Success of Reformers 97

Impact of Reformers on Store Management 99

$\begin{array}{ll}\text { Company Paternalism } & 101\end{array}$

Greater Autonomy for Clerks 107 
V. CONCLUSION

REFERENCES 


\section{CHAPTER I}

\section{INTRODUCTION}

In 1911 Chicago reformer Louis DeKoven Bowen wrote with concern that work in the city's department stores made "it difficult for girls to withstand the temptations which press hard upon them, and which lead to a moral as well as a physical breakdown." Bowen's pamphlet titled, "The Department Store Girl," highlighted the growing concern that many, particularly within the middle-class, felt toward female department store clerks. ${ }^{1}$ As Bowen explained, "the department store girl is much more subject to temptation than is the girl who works in the factory... [she] meets a large number of other people and is constantly surrounded by the articles which are so dear to the feminine heart." "2 Her implication was that saleswomen would desire expensive clothing, accessories, and other luxuries sold in their workplace and would acquire them through illicit relationships with their male customers. For Bowen and like-minded reformers, un-regulated labor in the department store could open a young woman up to serious questions about her moral character, entice her toward vice, and threaten the middle-class values that they wished to promote. To resolve these potential threats, reformers sought to improve working conditions and regulate the behavior of clerks. These efforts, and the social concerns they sought to assuage, emerged out of larger factors, namely, the

\footnotetext{
${ }^{1}$ Louise DeKoven Bowen, The Department Store Girl: Based Upon Interviews with 200 Girls (Chicago, Juvenile Protective Association of Chicago, 1911), 1.

${ }^{2}$ Ibid, 4-5.
} 
reaction of Victorians to a growing consumer culture and changing notions of respectability. Department stores had the distinction of being both emblematic of these changes and uniquely positioned to serve as host to the conflicts that stemmed from them.

It is important to establish why people at the turn-of-the-century would have viewed department stores with such anxiety and identified them as a possible source of moral decay. At the turn-of-the-century, consumerism was becoming an increasingly important factor in American public life. It was not only affecting or influencing people's personal behavior, but was creating what William Leach calls the "land of desire," a new secular culture in which traditional, Victorian values were replaced by values of a consumer culture. In this new culture, "acquisition and consumption [were] the means of achieving happiness." The concept of "newness," so familiar to Americans, was subverted to inspire insatiable consumerism and merchants appealed to the nation's love for democracy to encourage consumption by all citizens. The emphasis placed on the monetary value of nearly everything was altering the moral values that many Americans had previously embraced. ${ }^{3}$

Shifts in values magnified all kinds of social stresses, including those between the genders, between different racial and ethnic groups, and between different social classes Tensions between the genders and social classes, in particular, were a frequent source of discussion in the news media and consistently appear in archival materials from department stores during the time period. Furthermore, the tensions surrounding class and gender were most apparent because racial and ethnic minorities were widely

\footnotetext{
${ }^{3}$ William Leach, Land of Desire: Merchants, Power, and the Rise of a New American Culture (New York: Vintage Books, 1993), 3.
} 
excluded from department store sales staff. Saleswomen in large, downtown stores were overwhelmingly white and native-born. ${ }^{4}$

As women became the primary shoppers for their families and the culture of consumption encouraged greater expenditure, their negotiations with male family members became more consequential. As more female store clerks entered the workforce to accommodate growing consumer demand, their presence in the public space generated debate with men as well. Similarly, because all social classes were invited to take part in the new consumer culture, each group naturally questioned the behaviors of the others and debated how they would impact society as a whole.

For many Americans, this new culture of desire was very attractive because it promised personal freedom, through a consumer's individual choices, and even salvation, or the ability to remake oneself, through the purchase of goods. ${ }^{5}$ The outlook of many Americans, particularly the middle-class, was one filled with great excitement, but also uncertainty and even fear. Members of the middle-class could see a new consumer society developing around them and felt as though they were losing some of the control that they believed they had over the well-being of their communities. The individualism of the consumer culture upset traditional expectations within the family and generated dissatisfaction when desires could not be fulfilled. As Leach explains, the democratization of desire did not ensure the equal distribution of political power or economic resources. Consequently, "[desire] often set husbands against wives, children

\footnotetext{
${ }^{4}$ Susan Porter Benson, Counter Cultures: Saleswomen, Managers, and Customers in American Department Stores, 1890-1940 (Urbana: University of Illinois Press, 1986), 209.

${ }^{5}$ Leach, Land of Desire, 4.
} 
against parents...it fostered anxiety and restlessness and, when left unsatisfied, resentment and hatred."

Department stores became a reflection of the new culture of consumption. Unlike the specialized stores that preceded them, the ambition of department stores was to fulfill all of the needs of the growing consumer culture. As the desires of consumers expanded, so did the number and variety of goods available in department stores. ${ }^{7}$ The stores could continually expand and adapt to customer's tastes, because of their access to capital. Within the department store, it was possible to view nearly every type of product that Americans were producing or importing. ${ }^{8}$ The large stores were open to all, rich and poor alike, permitting anyone to browse without the pressure of buying. Their windows and public spaces encouraged anyone who passed by to enter and enjoy the sights and amenities of the store. ${ }^{9}$ Stores were places of possibility where patrons could affirm their social status or express their ambition through their purchases. ${ }^{10}$

The department store serves as an interesting place to study this moment in modern America because it is a creation of a time period when interplays between classes and genders were dramatically changing. The same tensions that were playing out in everyday life were magnified in the department store. Clerks in particular are interesting because this position was an aspirational job, due to its relatively high status, while at the same time it was still an entry level position. It conveyed a sense of style and glamour that other jobs did not have. There was also the chance of promotion, although this hope

${ }^{6}$ Ibid, 7.

${ }^{7}$ Benson, Counter Cultures, 14.

${ }^{8}$ Leach, Land of Desire, 23.

${ }^{9}$ Benson, Counter Cultures, 19-20

${ }^{10}$ Elaine S. Abelson, When Ladies Go A-Thieving: Middle-Class Shoplifters in the Victorian Department Store (New York: Oxford University Press, 1989), 46. 
was often drawn from an optimistic view of store policy. For these reasons, Susan Porter Benson, has called salesmanship the "Cinderella of Occupations."11 Some saleswomen earnestly believed that one day they could become a buyer and travel to Paris. ${ }^{12}$ Many young women thus wanted to be clerks, but not every girl could be a clerk. Most store clerks were white and native-born and had to be able to project a middle-class persona. ${ }^{13}$ Even though most clerks were not middle-class themselves, projecting this image was seen as necessary for the comfort of middle-class customers.

Store management often sought control over saleswomen because it provided a sense of influence over an emerging culture which was largely outside of their control. The department store had become an institution of mixed messages, projecting the idea that the culture of consumption should be open to all, but a source of stress over the resulting culture clash between social classes. Because store managers hailed primarily from the middle-class, they carried a reform-minded worldview directly into the store. Store archives reveal these influences over time in their rules and procedures. Company rule books show increasing concern for working conditions and dress codes, while internal reports, such as the 1920 J.A. Houser report, reveal an increased emphasis on the education and the professionalization of clerks. Middle-class reforms, such as restrictions on working hours, calls for better pay, and praise for some store welfare programs, became a way that middle-class reformers could exert their own control over saleswomen. By promoting these reforms and encouraging policy changes in stores, people like Louis DeKoven Bowen were trying to ease middle-class anxieties over the

\footnotetext{
${ }^{11}$ Benson, Counter Cultures, 177.

${ }^{12}$ Sarah Smith Malino, "Faces Across the Counter: A Social History of Female Department Store Employees, 1870-1920," PhD diss, (Columbia University, 1982), abstract, 2.

${ }^{13}$ Malino, "Faces Across the Counter," 26.
} 
changes occurring throughout American society. It is somewhat ironic that at the same time reformers were trying to enact greater dominance over the working class in the department store, the department store was enabling working class people, through the democratization of desire, to express their individualism through consumption.

This thesis explores the experience of the female department store clerk, particularly how she related to the men she encountered in the workplace, the middleclass customers who shopped in Chicago's main stores, and the middle-class reformers who showed keen interest in her life both at work and at home. Focusing on the transitional period between 1880 and 1930, I highlight how gender and class conflicts arose from middle-class expectations that were thrust upon these women and in turn, how those middle-class expectations were largely formed by the sentiments of Chicago's active reform community. Often, the mentalities of Chicago's middle-class and its reformers were one and the same. Women comprised the majority of social reformers in the city and they were the sisters, wives, and daughters of the middle-class, male department store managers. ${ }^{14}$ Consequently, the store's managers brought the ideas of the reformers to the forefront, if not always directly than indirectly through their value systems. I describe how ultimately this was beneficial to the stores because it inserted these values onto the sales floor and pleased the store's middle-class clientele. The benefit and harm that these efforts had on working women are also be highlighted. As middle-class women took up the cause of expanding women's rights, they pressured the department store to do the same and greatly improved the working lives of clerks, but they also denied clerks full agency over their working lives. Yet, this thesis also

\footnotetext{
${ }^{14}$ Maureen A. Flanagan, Seeing With Their Hearts: Chicago Women and the Vision of the Good City, 1871-1933 (Princeton: Princeton University Press, 2002) 10.
} 
acknowledges the ways in which clerks themselves worked to better their working environment. Ultimately, I demonstrate the significant improvements for saleswomen that resulted from a combination of changing values, middle-class activism, and selfadvocacy.

As a city, Chicago has an important place in retail history because of the great stores that had their start there, notably Marshall Field's and Carson Pirie Scott. Consequently, institutions around the city hold a wealth of large archives that are available for researchers. Additionally, Chicago's reform movement history makes it unique amongst other American cities. While the sensibilities of its middle-class were probably not all that different in comparison to other major cities, the vigor of its reform movement was remarkable. As historian Maureen Flanagan explains, Chicago was a place where female reformers worked in solidarity "despite differences of class, race, and ethnicity."15 While perhaps their larger vision of a city secure and prosperous for all was not realized, Chicago's reformers gained small but important victories. ${ }^{16}$ These limited reforms, regarding working hours, compensation, and treatment by employers, created better working conditions for many of the city's department store employees. Chicago thus provides fruitful ground for the major research questions and focus of this text.

\section{Historiography}

Historians have given considerable attention to the rise of consumer culture and the development of the department store around the turn-of-the-century. Comparatively less attention has been given to the women laboring in the great stores, with much of the existing scholarship on female department store employees focusing on the importance of

${ }^{15} \mathrm{Ibid}, 6$.

${ }^{16}$ Ibid, 200. 
social class and gender. Of these, Susan Porter Benson's Counter Cultures: Saleswomen, Managers, and Customers in American Stores 1890-1940 offers the most comprehensive analysis. Benson suggests that female department store employees were usually the beneficiaries of larger social changes, rather than a driving force behind them. Benson contends that work in department stores offered career opportunities that might not have been possible for women a generation before. However, a major theme of the book is that these expanded opportunities came with costs, particularly in the form of class conflict. Benson suggests that class conflict was nearly omnipresent, existing between the saleswoman and her customers, the saleswoman and store management, or both. Sarah Smith Malino's dissertation, Faces Across the Counter: A Social History of Female Department Store Employees 1870-1920, covers similar material to Benson's book. However, while Benson's book focuses on many of the conflicts that saleswomen faced, Malino's addresses more of the positive aspects of department store work. She discusses at length the welfare services provided by companies. Benson dismisses many of these programs as paternalistic, while Malino sees them as mostly positive. She contends that even if they reinforced negative gender stereotypes of the time period, they offered "respectable work, middle-class manners, and economic and social independence." ${ }^{17}$ The main theme of Malino's study is that the work of female department store employees became a skilled profession, bringing the benefits of this type of work to a new class of women and helping them to overcome older class and gender barriers $^{18}$

\footnotetext{
${ }^{17}$ Malino, "Faces Across the Counter," 103.

${ }^{18}$ Ibid, 332 \& 335.
} 
Benson and Malino's works are heavily sourced from the cities of the Northeast. Scholars have not widely examined the history of female department store employees in the Midwest, but Joanne Meyerowitz has written about the broader topic of female labor in the city of Chicago in her book, Women Adrift: Independent Wage Earners in Chicago, 1880-1930. On the whole, Meyerowitz's depiction of female labor is far more pessimistic than the authors previously mentioned. Unlike Benson and Malino, she finds that most single, working women were not offered opportunities because they were unable to break free of the constraints of societal judgment. It is important to remember that Meyerowitz's subjects were not typical, as most female workers in Chicago did not live independently. ${ }^{19}$ However, her work provides a helpful understanding of the struggles of working women in the city, both in the department store and those employed in other fields. Lisa Fine has also explored employment opportunities for women in Chicago in her book, The Souls of the Skyscraper. She describes the feminization of clerical work in the city as the result of both economic conditions and the initiative taken by young women to seek the education and training necessary for these jobs. ${ }^{20}$ She acknowledges the limitations that followed the identification of clerical work as "women's work," while also recognizing the promise that it initially offered for higher paying and satisfying work. Yet, Fine's subjects were also atypical, as most clerical workers were white, middle-class, and well-educated. ${ }^{21}$ Accordingly, her work can offer interesting comparisons between the experiences of middle-class clerical workers and working-class saleswomen.

\footnotetext{
${ }^{19}$ Joanne J. Meyerowitz, Women Adrift: Independent Wage Earners in Chicago, 1880-1930. (Chicago: University of Chicago Press, 1988), 8.

${ }^{20}$ Lisa M. Fine, The Souls of the Skyscraper: Female Clerical Workers in Chicago, 1870-1930. (Philadelphia: Temple University Press, 1990), xvi.

${ }^{21}$ Fine, Souls of the Skyscraper, xvii.
} 
Existing scholarship has provided a good general overview of the history of the rise of the female clerk and the evolution of her job over time. Some works have gone a step further and examined the gender and class conflicts within the department store. However, there is still a great deal of depth and breadth than can be added to this historiography. Neither Benson, nor Malino, discuss the role of middle-class reformers at great length in their works. This influence was particularly strong in places with a robust reform community, like Chicago. Another weaknesses of the existing work on department stores is that it focuses almost exclusively on sources from the cities of the Northeast. Given that Meyerowitz chose to focus on Chicago because it contained relatively "average" demographics for a large American city, there is value in discovering whether research on department store clerks in a Midwestern city supports or refutes similar scholarship sourced from the Northeast. Based on my reading of primary sources from Chicago, I believe that their conclusions do have validity beyond the Northeast. This thesis seeks to explore the intersection of Chicago's reform movement and booming department store business in order to complement to the work done by Benson, Malino, Meyerowitz, and others.

\section{Use of Primary Sources and Chapter Overview}

In addition to synthesizing secondary sources on the emergence of consumer culture, department stores, and Progressive-era reform, this thesis makes extensive use of primary sources. I analyze the unique holdings of the Chicago Historical Society from Marshall Fields and Carson, Pirie, Scott, \& Company, including rule books and internal reports. These collections were acquired by the historical society in 2007 after much of the historiography on department stores was written. As such, many of the items in these 
collections have yet to be extensively utilized by historians. This thesis also explores the contributions of Chicago's reform community, including written work by Jane Addams and Louise DeKoven Bowen and the extensive testimony provided at a 1913 State Senate Committee Hearing which focused on the working conditions in department stores. Lastly, the thesis draws on the extensive coverage of department stores in Chicago's newspaper of record, the Chicago Tribune.

In focusing on the nexus of the working-class culture of saleswomen and the middle-class culture of customers and management in the department store, this thesis discusses the origins and evolution of these intersections. In chapter two, I describe the emergence of consumer culture and the cultivation of female shoppers. Chapter three builds upon that foundation by discussing the tensions that this created between Victorian and more modern value systems. The chapter also describes the growth of the department store and the employment of female saleswomen. Lastly, chapter four describes the Chicago reform movement, their interest in department stores clerks, and the gradual improvements that took place in the working lives of saleswomen. 


\section{CHAPTER II}

\section{THE GROWTH OF CONSUMERISM}

The great stores that lined Chicago's State Street and employed tens of thousands of saleswomen did not appear suddenly. Their existence came about as the result of decades of change in American society. As the nation experienced rapid urbanization and industrialization, its impressive productivity necessitated the creation of the culture of consumption. This culture challenged prevailing Victorian values of thrift and selfdenial, while it also provided new ways for Americans to express themselves and seek fulfillment. The "democratization of desire" made all Americans participants in the new consumer culture, but at the same time created conflicts along gender and class-lines. It was this culture of consumption with its benefits and failings that gave rise to the department store and with it the female clerk.

Changes in American Business and Consumer Behavior

After the Civil War, the United States began to undergo changes that would transform economic production and consumption. The invention of mass-manufacturing equipment and the discovery of new sources of energy enabled industrial output to rapidly expand. Telephone, telegraph, and railway lines crisscrossed the country and allowed businesses to spread nation-wide. A continuous migration of workers from the countryside and abroad ensured that factories had an adequate supply of laborers. Producers took full advantage of the huge amounts of capital made available by banks 
and insurance companies. The new corporations that emerged in this climate produced huge quantities of goods and engaged in cut-throat competition that lowered the price of consumer products. ${ }^{22}$ Manufacturers soon worried that existing distribution systems would not be able to unload goods quickly enough or that overproduction would wipe-out profits. Increasing consumption would help to alleviate these concerns and maintain demand, so wages were steadily increased to give workers greater spending power. ${ }^{23}$ By the turn of the century, production in America's cities had reached a critical point as capital goods, the materials used to construct the nation's infrastructure and industrial machinery, were no longer the driver of economic growth due to slipping demand. Manufacturers realized that the sale of small goods was the key to future growth. A culture of consumption would create an endless demand for new and replacement products that could better match industrial output. ${ }^{24}$ In his classic, The Search for Order, Robert Wiebe connects the national obsession over quantity to the feelings of disorder shared by many. As businesses measured their success in the number and variety of goods they were able to produce, individuals measured their success by their ability to purchase and consume those goods. ${ }^{25}$

Corporations made it their long-term strategy to change the way that Americans thought about spending by encouraging a culture of consumption. Business owners, including department stores, promoted well-being and personal satisfaction as sideeffects of increased consumption. Men and women who had little control over their working lives in an industrial society sought comfort and felt empowered by the ability to

\footnotetext{
${ }^{22}$ Leach, Land of Desire, 17.

${ }^{23}$ Ibid, 36.

${ }^{24}$ Maureen A. Flanagan, America Reformed: Progressives and Progressivisms, 1890s-1920s (New York: Oxford University Press, 2007), 181.

${ }^{25}$ Robert H. Wiebe. The Search for Order, 1877-1920. (New York: Hill and Wang, 1967), 40-41.
} 
make choices as consumers. ${ }^{26}$ The new culture of consumption challenged traditional Victorian values as the world of consumerism replaced the family as the focus of middleclass life. ${ }^{27}$ Businessmen tried to undermine the older culture of thrift and began to appeal directly to the consumer's desire for goods rather than their need. ${ }^{28}$ To encourage this shift, retailers had to create strategies to overcome the conflict in values through creative advertising. They reconciled these opposing values by promoting consumption as a domestic obligation. Women were told that in shopping and consuming, they were nurturing their family and maintaining their respectability. ${ }^{29}$

Urbanization proved to be essential in the process of spreading this new consumer culture. In his book, The Incorporation of America, Trachtenberg argues that the economic success of cities was guaranteed by municipal assistance to growing industries in the production and distribution of goods. New transportation and communication systems allowed businesses to coordinate efforts between factories, offices, and retail outlets within a metro area to ensure the rapid and reliable manufacture of goods. Undergoing rapid growth, cities were being expanded in a planned manner by local government, corporations, and urban planners, like the renowned Frederick Olmsted. ${ }^{30}$ Trachtenberg argues that Olmsted saw cities as essentially large marketplaces operating as "site[s] of trade and consumption" where people of different classes exchanged goods. Olmstead divided this marketplace between goods that were easily traded and property that was held more permanently. He observed that cities, assisted by improved

\footnotetext{
${ }^{26}$ Richard Wightman Fox and T. J. Jackson Lears, ed., The Culture of Consumption: Critical Essays in American History, 1880-1980 (New York: Pantheon Books, 1983) xi.

${ }^{27}$ Abelson, When Ladies Go, 27.

${ }^{28}$ Ibid, 31.

${ }^{29}$ Ibid, 28.

${ }^{30}$ Alan Trachtenberg, The Incorporation of America: Culture and Society in the Gilded Age (New York: Hill and Wang, 2007;1982), 116-117.
} 
transportation and communication, were beginning to move away from tangled neighborhoods of mixed residential, commercial, and industrial development in favor of the separation of residential communities and downtown marketplaces where goods could be exchanged. Olmsted believed that dividing cities into areas for "commercial" and "domestic" activities essentially promoted the exchange of small goods, while also protecting more permanent property investments that promoted social order and looked out for private investment. ${ }^{31}$

While Weibe and Trachtenberg have contributed greatly to our understanding of the urbanization of America, these historians have done so largely without paying recognition to the complex roles that women played during this period. Women's historians, such as Carrol Smith-Rosenberg, have provided for a richer understanding of the consequences of the rural to urban shift by fully acknowledging the role that women played in the urban environment. In Disorderly Conduct, Smith-Rosenberg acknowledges the value of the narrative of urbanization established by Weibe, but stresses that women were a part of and not separate from it. She explains how middleclass, urban women who had previously not been active in public or feminist causes were mobilized during the Civil War and remained so thereafter. As they did so, they brought with them the ideas of the "Cult of True Womanhood," a formulation by Victorian men that a women's natural place was in the home, living as a dutiful wife and mother into the public sphere. In doing so, they became the "housekeepers of America," intent on reforming urban problems and responding to the changing economy. ${ }^{32}$ She argues that Victorians felt that the disorder that Weibe describes as creating anxiety for so many

\footnotetext{
${ }^{31}$ Ibid, 108-109.

${ }^{32}$ Carroll Smith-Rosenberg, Disorderly Conduct: Visions of Gender in Victorian America, (New York: A.A. Knopf, 1985), 173.
} 
people could be controlled by the work of the virtuous "True Women." In this way, Smith-Rosenberg's analysis is essential for tracing the origins of reform culture back to the urbanization of the late 1800s.

It was this urbanization that enabled cities to be transformed into centers of consumption. During this transition, there was undoubtedly a public fascination with the money generated from industrialization. The Old World view of money as something reserved only for the rich was replaced with the hope that wealth would be democratized through consumption. In buying goods, men and women of all social classes could be personally transformed. ${ }^{33}$ T. J. Jackson Lears argues that this behavior allowed individuals to improve their standard of living by purchasing goods that helped them to live the "good life." At the same time, in this pursuit the consumer became both buyer and seller because many goods that were bought were done so with the intent of improving a person's public image. Lears contends that this "self-absorption" developed simultaneously with the culture of consumption. ${ }^{34}$ In her book on women's consumer practices, Cheap Amusements, Kathy Peiss, like Lears, explores the ability of goods to transform and mold a person's image. One example she provides is working-women's use of fashionable clothing to communicate their social aspirations and command respect. ${ }^{35}$ The women in Peiss' work reflect Trachtenberg's understanding of how the term "consumption" was used from the last decade of the nineteenth century onward. $\mathrm{He}$ argues that by that time, the term "consumption" was no longer used to describe goods

${ }^{33}$ T. J. Jackson Lears, Rebirth of a Nation: The Making of Modern America, 1877-1920 (New York: HarperCollins, 2009) 52.

${ }_{35}^{34}$ Fox, Culture of Consumption, xii.

${ }^{35}$ Kathy Lee Peiss. Cheap Amusements: Working Women and Leisure in Turn-of-the-Century New York (Philadelphia: Temple University Press, 1986), 63. See also: Nan Enstad, Ladies of Labor, Girls of Adventure: Working Women, Popular Culture, and Labor Politics at the Turn of the Twentieth Century (New York: Columbia University Press, 1999), 63. 
that were squandered or wasted, but ones that were used to fulfill a person's wants and needs. ${ }^{36}$ Dominant cultural values were changing as people began to view consumerism as the key to happiness, not hard work.

In the early nineteenth century, America's focus on production symbolized abundance and paradise to many and fostered the hope that the nation could become a place where hard work defeated poverty. By the turn-of-the-century, this mindset was changing as production became a way to fuel and sustain a culture of consumption increasingly focused on personal gratification. Lears characterizes the change as a shift from an ethos of "perpetual work, compulsive saving, civic responsibility, and a rigid morality of self-denial" to one of "periodic leisure, compulsive spending, apolitical passivity, and... individual fulfillment." ${ }^{, 37}$ In his book, Land of Desire, William Leach argues that "the cult of the new [and] the democratization of desire" were key features of the new consumer culture. The new culture was revolutionary because it did not have roots in existing family, religious, or political culture. ${ }^{38}$ Leach argues that the "cult of the new" dominated this emerging culture because Americans were used to viewing themselves as a nation of newness and change. ${ }^{39}$ Furthermore, consumer capitalism was dependent on the "cult of the new" to maintain a steady demand for new products. Old customs, traditions, and religion had little place in this new culture. At the same time, Leach observes, the nation projected a "democratization of desire." When the country began to rapidly industrialize in the late nineteenth century, the vision of America as a paradise for all was being challenged. Small numbers of people controlled the capital

\footnotetext{
${ }^{36}$ Trachtenberg, The Incorporation of America, 130.

${ }^{37}$ Lears, Rebirth of a Nation, 3.

${ }^{38}$ Leach, Land of Desire, 3.

${ }^{39}$ Ibid, 4.
} 
that created wealth in this new economy and urban workers lost control over their labor. ${ }^{40}$ On the other hand, wages and standards of living were on the rise. Leach says that consumerism led workers to believe that they could practice democracy through their ability "to desire, long for, and wish for whatever they pleased." Regardless of age, ethnic group, race, or gender, all people were able to feel as though they had the same right to desire commercial goods as anyone else. ${ }^{41}$ Central to this argument is that these changes were largely engineered by the great entrepreneurs of the age. ${ }^{42}$ As previously stated, the "democratization of desire" replaced any real potential for economic equality. As entrepreneurs manipulated customers into a false sense of equality, it benefitted the merchant's bottom-line, but did not reduce real inequality.

Conversely, Jackson Lears views the American public as the drivers of change. His argument centers on the need for regeneration in the decades following the Civil War. People from all facets of American life sought this regeneration and their personal attempts to garner it created a collective change in values which included acceptance of a consumer culture. ${ }^{43}$ Jill Fields explores this idea extensively in her book on female undergarments, An Intimate Affair, as she discusses the considerable efforts made by producers to manipulate the behavior of consumers. In their attempts to dictate the "fashionable" and "proper" shape of a woman's body, producers heavily used advertising and trade journals to promote their position. Women pushed back and asserted their tastes and preferences by dissenting through their fashion choices. Manufactures and

\footnotetext{
${ }^{40}$ Ibid, 5 .

${ }^{41}$ Ibid, 6.

42 Ibid, 15.

${ }^{43}$ Lears, Rebirth of a Nation, 1.
} 
retailers were forced to alter their offerings and accommodate customer demands. ${ }^{44}$ The culture of consumption was clearly not driven by business elites alone and women played an important role in asserting themselves through this new culture. Lears characterizes the 1880 s and 1890 s as a period in which "the social order seemed very much up for grabs." 45 He believes that the moral climate of the time was favorable toward a shift to greater consumerism and that the efforts of entrepreneurs, particularly in advertising, built upon that. ${ }^{46}$ In this way Leach's argument can be seen as somewhat compatible with that of Lears, as the titans of the department stores that Leach focuses on were operating within and exploiting the landscape that Lears describes. The culture of consumption being developed by both entrepreneurs and consumers gradually made its imprint on many aspects of American life.

The democratization of desire and the disruption to the social order it engendered demanded changes within American society. Families faced conflict as their members disagreed about finances in a consumer culture now driven by individual choices. Money was necessary to buy subsistence and security, creating a reliance on wage and salary incomes. ${ }^{47}$ Most aspects of American life could now be boiled down to their impact on personal or business finance as the value of personal morality, relationships, and aesthetics were judged on their ability to assist consumption. ${ }^{48}$ Consumption created anxieties for many Americans. Some were fearful that they were being tricked into buying goods from untrustworthy merchants or being sold inferior products. ${ }^{49}$ Not only

\footnotetext{
${ }^{44}$ Jill Fields, An Intimate Affair: Women, Lingerie, and Sexuality (Berkeley: University of California Press, 2007), 56.

${ }^{45}$ Ibid, 90 .

${ }^{46}$ Fox, Culture of Consumption, 4.

${ }^{47}$ Leach, Land of Desire, 7.

${ }^{48}$ Ibid, 8.

${ }^{49}$ Lears, Rebirth of a Nation, 52.
} 
was the morality of sellers called into question, but also of the consumers themselves. Moralists, especially those in the middle-class lamented the negative influence that consumerism was having on society.

\section{Consumerism and Social Class}

While all social classes participated in the new consumer culture, ethnic identity and economic means created differences in customer behaviors. Generally speaking, members of the working class gained considerable spending power during the latter part of the nineteenth century. Wages for non-agricultural workers increased by fifty percent between 1870 and 1900 and manufacturing wages climbed another twenty-five percent in the first two decades of the twentieth century. Working hours were also on the decline, dropping dramatically between 1900 and 1910 to an average of about 50 hours per week. ${ }^{50}$ Rising wages were precisely the lift that growing American industries were looking for. Mechanization facilitated production at high levels, and retailers, such as emerging department stores, assisted distribution, but American wages in the 1870s were still too low for most workers to fully participate as consumers. Economists began to challenge conventional wisdom that argued that scarcity alone would be enough to drive up profits and instead began to theorize that rising wages might be the key to economic growth. ${ }^{51}$ The latter proved to be true and with greater disposable income and more leisure time laborers were increasingly able purchase more goods and to enjoy commercial entertainment. Theaters, amusement parks, and dancehalls all competed for the entertainment dollars of the working-class. This emerging entertainment industry was

\footnotetext{
${ }^{50}$ Roy Rosenzweig, Eight Hours for What We Will: Workers and Leisure in an Industrial City, 1870-1920. (New York: Cambridge University Press, 1983) 179.

${ }^{51}$ Lears, Rebirth of a Nation, 90.
} 
part of the wider culture of consumption taking over the nation. ${ }^{52}$ To be sure, increased prosperity of the working class was not universal, and many families continued to live in abject poverty. Before the Great Depression, over one in five Americans lived at a level of poverty that made it difficult for them to fund an adequate diet and housing, leaving almost nothing for recreational expenditures. ${ }^{53}$ It is reasonable to assume that these working-class families also would have severely limited their spending on consumer goods.

Minority groups were participants in the new consumer culture, but they were severely restricted by the racism of the period. In the Midwest, minorities were typically not prevented from shopping in department stores, but their presence there was extremely limited due to the hiring policies of stores and the pervasive self-imposed segregation of cities like Chicago. Data on the employment of women adrift in Chicago reveals that in 1910 none of the fifty-three African American women surveyed worked in sales. ${ }^{54}$ In her book on African American women in Detroit, Victoria Wolcott explains that African American women were reluctantly hired as elevators operators in stores in the early 1900s, but it was not until the 1950s and 1960s that they were hired as saleswomen. ${ }^{55}$ Hispanic women found their job prospects similarly limited. ${ }^{56}$ It is reasonable to assume therefore, that lacking a presence in the store workforce and likely feeling highly uncomfortable in an overwhelmingly white shopping environment, minority customers took their business elsewhere. Working-class and immigrant customers often felt out of

${ }^{52}$ Rosenweig, Eight Hours, 180.

${ }^{53}$ Ibid, 181.

${ }^{54}$ Meyerowitz, Women Adrift, 32.

${ }^{55}$ Victoria W. Wolcott, Remaking Respectability: African American Women in Interwar Detroit. Gender and American Culture (Chapel Hill: University of North Carolina Press, 2001), 78, 245.

${ }^{56}$ Kessler-Harris, Alice Kessler-Harris, Out to Work: A History of Wage-Earning Women in the United States (New York: Oxford University Press, 2003), 311. 
place in department stores geared toward middle-class patrons and chose to patronize neighborhood stores instead. Here, they felt that they were respected and valued as customers. ${ }^{57}$ It is likely that minority customers felt similarly and shopped within their own neighborhoods instead of downtown.

Due to the fact that many minority and working-class customers were dissuaded from shopping in department stores, the cultural concerns about consumerism within the stores were usually strongest within white, middle-class society. Victorian values placed a great deal of importance on thrift, and people of the late nineteenth century tended to assign different economic expectations based on social class. The middle-class was expected to practice tight money management and embrace a secularized version of the Protestant work ethic with the aim of improving their economic standing. ${ }^{58}$ This outlook clashed with the new culture of consumption. In A Fierce Discontent, Michael McGerr argues that the middle-class felt a strong temptation to consume to assert their class identity, but at the same time felt overwhelmed by those desires. Consequently, they vented their frustration over their own struggles by attacking the spending habits of the upper and lower classes. ${ }^{59}$ Meanwhile, before the turn of the century, the upper-class had begun to abandon personal thrift in favor of excessive spending to celebrate their Gilded Age wealth. The disgust that many members of the middle-class felt toward upper-class largess motivated them to advocate for restraint within their own social class. ${ }^{60}$ This conspicuous consumption was likewise criticized by Thorstein Veblen who argued that

\footnotetext{
${ }^{57}$ Benson, Counter Cultures, 78.

${ }^{58}$ Lears, Rebirth of a Nation, 78.

${ }^{59}$ Michael E. McGerr, A Fierce Discontent: The Rise and Fall of the Progressive Movement in America, 1870-1920 (New York: Free Press, 2003), 61-62.

${ }^{60}$ Ibid, 13.
} 
the luxurious spending of the wealthy trickled down to the working-classes as they spent money on items that they could not afford. ${ }^{61}$

Interestingly, both the upper and middle-classes had relatively low expectations for the thrift and savings habits of the poor and working-class. Many observers praised working-class women who managed to successfully maintain a family budget despite low wages and economic downturns. ${ }^{62}$ Conversely, the same observers could be very critical of working-class men who failed to provide for their families or members of the workingclass who spent more than their income. Criticisms not only came from the upper and middle-classes, but from within the working-class itself. Moralists often placed blame on the personal failings of the poor, stressing the importance of self-denial and a resistance to impulse buying. ${ }^{63}$ Members of the working-class realized that the constant threat of low wages, job loss, and injury could put their livelihood in jeopardy. Considering these dangers, individual spending was sometimes viewed as careless and even immoral. ${ }^{64}$ Victorian middle-class moralists were quick to find fault with excessive spending within the working-class, but were increasingly distressed with the expenditures of their own class as well. After all, it was the middle-class that was supposed to practice thrift and wisely use family funds to better their lives. ${ }^{65}$ This emphasis on frugality was often intertwined with Christian values and served as a major theme of nineteenth century religious revivals. ${ }^{66}$ At the same time, growing consumerism brought with it middleclass self-consciousness over social status. At a minimum, members of the middle-class

\footnotetext{
${ }^{61}$ Thorstein Veblen, The Theory of the Leisure Class (New York: Macmillan, 1902), 84.

${ }^{62}$ Lears, Rebirth of a Nation, 78

63 Ibid, 79.

${ }^{64}$ McGerr, Fierce Discontent, 13.

${ }^{65}$ Leach, Land of Desire, 67.

${ }^{66}$ Smith-Rosenberg, Disorderly Conduct, 153.
} 
needed to convey their social status through their consumption and many spent at higher levels that mirrored their social aspirations. ${ }^{67}$ Purchasing non-essential items became a way for the middle-class to differentiate itself from the working-class. Clothing, toiletries, dining, and gifts were purchased on stretched budgets or with loans. ${ }^{68}$ The mass production of such goods seemed to contain the possibility of limiting classdistinction based on goods, but the growing influence of fads and fashion changed that. Elaine Abelson argues that "the perception of an object became as important as its intrinsic qualities" and the middle-class began to solidify its identity by consuming the "right" types of goods. ${ }^{69}$ The department store served as the middle-man, serving as "a place of learning as well as of buying and selling," helping middle-class customers to select these "right" items. ${ }^{70}$ Creating desires for these items became a major priority for entrepreneurs.

\section{Encouraging Consumerism}

Department stores played a major role in fostering the culture of consumption through creating new kinds of desires. Merchandise was displayed and advertised in ways that convinced shoppers that any numbers of products were true necessities. ${ }^{71}$ Store owners hid the non-selling departments of the store, added glass and mirrors, and improved the light in to make the store and the products for sale as attractive as possible. This interior design made it clear that the sole purpose of the department store was consumption. $^{72}$ The use of space, light, and color was deliberately designed to make

\footnotetext{
${ }^{67}$ Leach, Land of Desire, 67.

${ }^{68}$ McGerr, Fierce Discontent, 61.

${ }^{69}$ Abelson, When Ladies, 33-34.

${ }^{70}$ Trachtenberg, Incorporation of America, 133.

71 Ibid, 130.

${ }^{72}$ Leach, Land of Desire, 75-76.
} 
customers comfortable in the store, encourage them to move closer to merchandise, and generate a powerful desire for the goods on offer. ${ }^{73}$ Trachtenberg argues that the department store became "a place of learning as well as buying."74 Industry was expanding at such a rapid rate that customers need to be trained to consume as well as to produce. Young people were encouraged to visit growing department stores to learn to shop and mothers were pressed to bring their children along with the hopes that younger generations would pick up the habit of consumption early and continue to spend throughout their lifetimes. ${ }^{75}$

The advertising industry likewise shifted in an attempt to make purchases a matter of habit, not just need, and to attach an emotional reaction to that consumption. ${ }^{76}$ From 1870 to 1900 , the amount spent on advertising multiplied to over ten times its previous volume. Advertisers had greater flexibility to determine the type, shape, size, graphics, and color of their advertisements. ${ }^{77}$ A holiday advertisement which appeared in the Chicago Tribune in 1880 appealed to female shoppers by providing gift suggestions for the men in their lives. In a style typical of the period, the advertisement consisted of multiple columns listing a variety of goods. The advertisement contained no images and only minor variations in typeface. The only visual appeal of the ad came from enlarged text declaring the "Holidays!" and listing the store name, "Harvey Bros." The emotional appeal of the ad was limited to whatever personal connection the viewer might make with the names father, lover, son, and brother. ${ }^{78}$ A Carson Pirie Scot \& Company

\footnotetext{
73 Ibid, 73.

${ }^{74}$ Trachtenberg, Incorporation of America, 131.

${ }^{75}$ Flanagan, America Reformed, 195.

76 Trachtenberg, Incorporation of America, 135.

${ }^{77}$ Ibid, 136.

78 "Display Ad 5 -- no Title," Chicago Daily Tribune, Dec 12, 1880, 9.
} 
advertisement from the 1910 holiday season however, bears little resemblance to earlier ads except in the column layout. Categories of goods are accompanied with attractive images of the items being advertised. Descriptions of the products emphasize their quality, beauty, and stylishness, and similar products at different price points are advertised next to each other. Unlike the ads of earlier generations, the prices of goods are clearly displayed and often a point of emphasis. ${ }^{79}$ The democratization of desire that Leach speaks of was clearly evident in the changes within advertising. The images and vivid descriptions in the copy were intended to elicit desire, while the open declaration of pricing insinuated that people of varying economic means were all potential customers. As merchants renewed their advertising campaigns, an increasing number of manufacturers were purchasing advertising as well. This direct advertisement from manufacturer to customer created increased demand for recognizable brand names. New advertisements used persuasive language to transform newspaper and magazine pages into important components of product distribution. Corporate sales departments carefully choose the location and volume of their advertising to optimally promote the brand name. ${ }^{80}$ Advertisers presumed that their audience was often distracted and rushed when they viewed advertisements and adjusted their strategy accordingly. Ads were no longer focused on conveying information, but instead on attracting attention. ${ }^{81}$ Consequently, visual advertisements increased in importance. Attractive images were successful in selling products because they brought otherwise dull and inanimate objects to life. ${ }^{82} \mathrm{~A}$ 1916 advertisement for Maurice L. Rothschild, a regional clothing store chain, appealed

\footnotetext{
79 "Display Ad 15 -- no Title." Chicago Daily Tribune, Dec 19, 1910, 22.

${ }^{80}$ Trachtenberg, Incorporation of America, 136.

${ }^{81}$ Fox, Culture of Consumption, 17-18.

${ }^{82}$ Leach, Land of Desire, 54.
} 
to both brand identity and visual appeal. The advertisement is dominated by the image of a stylish man on the city streets. The headline copy reads "This store is the home of HartSchaffner\&Marx clothes.” The intended message was clearly, if you want to look your best while out and about in the city, dress yourself in HartScaffner\&Mart purchased from Rothschilds. ${ }^{83}$ Trachtenberg argues that advertisements became a sort of spectacle where information about the product and information about the customer were woven together. Through advertisements, consumers were shown a narrative describing how their experience with a product would result in their personal satisfaction.

Advertisements articulated a need to the customer and then provided them with the appropriate remedy. ${ }^{84}$ A 1910 Chas A. Stevens \& Bros. advertisement for women's wraps utilized the common approach of making goods seem simultaneously fashionable and practical. The image of a fashionable women draped in a luxurious wrap reads below, "Marabou sets in many styles are not only very fashionable but very becoming and are just the warmth needed for the cool fall days..." ${ }^{, 85}$ Noticeably absent from these advertisements were any reference to their production, which in turn would have connected the product with the labor that it was produced with. Advertisers preferred for their customers to view themselves as consumers rather than laborers because it enabled them to view themselves as middle-class and consume accordingly, further evidence of Leach's "democratization of desire" 86

In his book, Rebirth of a Nation, Jackson Lears argues that advertisements not only served to sell goods and promote consumption, but also served as a tool of

\footnotetext{
83 "Display Ad 7 -- no Title," Chicago Daily Tribune, Sep 20, 1916, 9.

${ }^{84}$ Trachtenberg, Incorporation of America, 137.

85 "Display Ad 8 -- no Title." Chicago Daily Tribune, Oct 15, 1910, 18.

${ }^{86}$ Trachtenberg, Incorporation of America, 139.
} 
assimilation for recently arrived immigrants. Through department stores and their advertising, merchants were sending strong messages to immigrants about what was needed to acquire an "American look." With the promotion of name-brands and department store goods, retailers were promoting a standardized version of the "American look" that they themselves had created. After successive generations, European immigrants were able to successfully model this look. ${ }^{87}$ Over time, American consumer goods became an important factor encouraging immigration in their own right. Immigrants often had dreams of the variety and quantity of goods that would be available to them in the United States. ${ }^{88}$

In her book, America Reformed, Maureen Flanagan argues that Americans in this period came to view consumption as a right that should be guaranteed to all citizens. This belief encouraged Progressive reformers to call for regulation and oversight to ensure the quality and safety of products on the market. Some even argued that the creation of consumers actually empowered the working-class because laborers had new leverage over their factory employers who needed to be able to stay on top of customer demand. ${ }^{89}$ In his 1925 essay, "Consumptionism," Samuel Strauss argued that Americans valued the continual increases in production and a rising standard of living above all other values. He also believed that consumers felt the urge to purchase goods that they did not even want. Manufacturers dictated what the people wanted, not the other way around. $^{90}$ To Strauss, this signaled a costly tradeoff, Americans had abandoned their

\footnotetext{
${ }^{87}$ Lears, Rebirth of a Nation, 122.

${ }^{88}$ McGerr, Fierce Discontent, 19.

${ }^{89}$ Flanagan, America Reformed, 195.

${ }^{90}$ Cited in Leach, Land of Desire, 265-266.
} 
democratic culture in favor of consumer comforts. ${ }^{91}$ This interpretation has been challenged by subsequent historians, such as in the work of Jill Fields mentioned previously, who argue that while influential, manufacturers were not the only drivers of production. ${ }^{92}$ Consumers, through their consumption choices, had powerful influence as well. Nonetheless, regardless of the precise extent of their influence on consumer behavior, entrepreneurs had an incredible amount of social influence, particularly though institutions like the department store.

\section{Women as Consumers}

By the time the culture of consumption emerged, women had been wellestablished as the primary consumers in American retail. Before the Civil War, most household goods were made by women in the home, but increasingly the development of manufactured food and clothing products meant that homemakers spent less time producing household necessities and more time shopping for them. The skills needed to produce household goods were replaced with the need to maintain a budget and make wise product selections. ${ }^{93}$

Early female shoppers were mostly upper-class urban women who browsed stores for pleasure. These women were a relatively small group, but they garnered much criticism from observers who denounced shopping as a dangerous habit which could lead to unnecessary overspending. The eventual expansion of female shoppers during the Gilded Age had a much greater impact on consumer culture than these earlier generations. This shift was due in large part to department stores that made consumption seem trouble-free and whose owners and managers tried to downplay moral objections.

${ }^{91}$ Cited in Leach, Land of Desire, 267.

${ }^{92}$ Fields, An Intimate Affair, 56.

${ }^{93}$ Trachtenberg, Incorporation of America, 129. 
Sellers engaged in aggressive marketing techniques in the hopes that customers would convince themselves of the necessity of product. Eventually, department stores were able to persuade middle-class women not to make purchases because they needed an item, but because they desired it. ${ }^{94}$ As discussed earlier, stores slowly encouraged this transition. First, in stocking greater varieties of consumables, such as food and clothing, and later by integrating a more diverse range of products. ${ }^{95}$ Some stores even provided daycare so that women could shop unencumbered by their young children. ${ }^{96}$ Department stores became a place where people were educated about which goods to purchase. ${ }^{97}$ The Victorian rules of thrift and savings began to be ignored in favor of maintaining a lifestyle commensurate with a family's social standing. ${ }^{98}$ Department stores were quick to exploit middle-class self-consciousness and provided the opportunity for these women to affirm their social standing and attractiveness through purchases. The disposable income of these customers was a prime target of enterprising department store owners and their attempts to awe customers was meant to thwart any resistance that these shoppers might feel towards parting with their spending money. ${ }^{99}$

Through shopping, elite and white women were able to directly participate in the economy, which was generally off-limits to them in the late nineteenth century. ${ }^{100}$ Shopping soon became a key activity in the lives of middle-class women, usually taking place multiple times per week for hours at a time. ${ }^{101}$ For working-class women, conducting the family's shopping was considered an important part in the nurturing of

${ }^{94}$ Abelson, When Ladies, 6.

${ }^{95}$ Trachtenberg, Incorporation of America, 130.

${ }^{96}$ Benson, Counter Cultures, 85.

${ }^{97}$ Trachtenberg, Incorporation of America, 132.

${ }^{98}$ Leach, Land of Desire, 68.

${ }^{99}$ Benson, Counter Cultures, 5.

${ }^{100}$ Abelson, When Ladies, 13.

${ }^{101}$ Ibid, 21. 
current and future generations of laborers. Shopping was delegated to women because it supplied the food and clothing needs of a family, needs that were traditionally produced by women when goods were made at home. ${ }^{102}$ These manufactured goods seemed to represent freedom for women, who could save hours versus producing them at home.

With more goods available and the standard of living rising, women were buying more goods that were seen as necessities as well as things that they wanted. ${ }^{103}$ Ready-towear clothing played an important role in this change. The production of clothing at home was a time consuming and labor intensive process. Manufacturers had to convince middle-class women to take advantage of the products that eased this burden and at the same time make them appear modern and fashionable. ${ }^{104}$ This was not always an easy sell because producing clothing was a large part of female identity. Eventually, it was ever changing styles that convinced women to save themselves the labor of constantly sewing new fashions and buy factory-made clothing. ${ }^{105}$ If a woman thought that a new wardrobe was necessary to attract male attention, send a message to her social circle, or better assimilate into American culture, it was easy to convince her to purchase affordable, ready-made fashions. Advertising also helped to convince middle-class women that they did not have to sacrifice quality when buying ready-to-wear goods. Merchants had convinced the public that goods produced by mass manufacturing were precisely made and expert in construction. Middle-class women were thus drawn into

\footnotetext{
102 Dana Frank, Purchasing Power: Consumer Organizing, Gender, and the Seattle Labor Movement, 1919-1929 (Cambridge England; New York: Cambridge University Press, 1994) 5-6.

103 Abelson, When Ladies, 25.

104 Ibid, 36.

105 Ibid, 37.
} 
stores because of the variety of manufactured goods that they carried, the growing needs of their families, and the satisfaction of making a purchase. ${ }^{106}$

At the same time, fashion was seen as incongruent with the Victorian value of thrift because many viewed it as frivolous and extravagant. From a middle-class point of view, silly women were being seduced into buying clothes by the stores that sold them. ${ }^{107}$ In reality, fashion was already an important way of communicating messages about social class and gender. Now clothing was also becoming a way that young women could project their individualism and sexuality. Fashion became a reflection of respectability as defined by middle-class women themselves. ${ }^{108}$ This was one way in which women were practicing Thorstein Veblen's theory of conspicuous consumption, which they viewed as a necessary part of their identity as members of the middle-class. ${ }^{109}$ Indeed the value of conspicuous consumption and the role of fashion within it was far from limited to the middle class, as subsequent historians, such as Peiss and Fields have pointed out.

Historians differ in their interpretations of what clothing choices tell us about working women of the time period. While middle-class women often accused workingclass girls of frivolously spending money to dress in middle-class fashions with the hope of marrying up the social ladder, Kathy Peiss argues that the working class utilized fashion to send important messages to the society around them. For example, new immigrants used clothing as a way to assimilate and gain acceptance in their new communities. Clothing that was reserved for Sundays was used to demand respect and

\footnotetext{
106 Ibid, 39.

${ }^{107}$ Lears, Rebirth of a Nation, 66.

${ }^{108}$ Fields, Intimate Affair, 3.

${ }^{109}$ Veblen, Theory of the Leisure Class, 75.
} 
communicate social standing. ${ }^{110}$ Young working women dressed in elaborate fashions both for their own pleasure and to convey their personality to others. ${ }^{111}$ Fashion became an escape, a way to forget about the troubles of work and family and a way to indulge in something entirely for oneself. ${ }^{112}$ Nan Enstad shares a similar viewpoint and argues that while middle-class women may have criticized working-class girls' attempts at dressing as something they were not, these women were inn fact asserting their rightful status. By dressing in this way, working-class women were advertising their demand for respect. ${ }^{113}$ William Leach holds a more critical view of messaging through clothing, believing that fashion had the potential to create anxiety for the individual. Men and women alike worried about the social-class ambiguity, feelings of inadequacy, and financial stress that fashion created. $^{114}$

When women traveled more frequently outside of the home to shop for family needs and updated fashions, they began to take on a larger public presence. Wealthy and middle-class women were fixtures in the downtown shopping districts where they browsed window displays and purchased goods, for pleasure as much as for work. Moralists saw this consumption of fashion as evidence of women's desire to show off their status and climb the social ladder. Men and women were both using fashion to project their social aspirations, but it was usually women alone who were publically criticized for this behavior. Trying to buy into a certain lifestyle strained family budgets,

\footnotetext{
${ }^{110}$ Peiss, Cheap Amusements, 63.

${ }^{111}$ Ibid, 64.

112 Ibid, 66.

${ }^{113}$ Enstad, Ladies of Labor, 10.

${ }^{114}$ Leach, Land of Desire, 92.
} 
forced many into debt, and added considerable stress to the lives of family breadwinners. $^{115}$

Few recognized that a daily reliance on manufactured goods also represented a new dependency on an "invisible" system of utilities which forced the outsourcing of security and comfort outside the home. ${ }^{116}$ The culture of consumption relied on a corporate structure that produced large quantities of goods and created a work environment that was more repetitive and rigorous. Workers were gaining economic freedom at the expense of many personal freedoms. ${ }^{117}$ Richard Whiteman Fox stresses this point when he argues that consumer culture entailed a power structure. "While the few make decisions about managing society, the many are left to manage their appearance," he writes. The economic choices available to Americans created merely an illusion of freedom, while the decisions that really drove consumer culture were being made by a small group of business elites. ${ }^{118}$ However, Fox adds that although average Americans were not making day to day decisions about the production and distribution of goods, they were not entirely powerless in this new system either. Workers were making a conscious choice to migrate to cities and participate in a growing consumer culture there. In most cases, they were incredibly eager to do so and enjoyed the freedom to make purchases that wage labor created. However, it is important to recognize that these choices did come with uncomfortable consequences for many Americans. The emerging consumer culture was liberating and exciting, but it also challenged prevailing notions about gender. Women played a powerful and public role in the new consumer culture in

\footnotetext{
${ }^{115}$ Lears, Rebirth of a Nation, 67.

116 Trachtenberg, Incorporation of America, 130.

${ }^{117}$ Lears, Rebirth of a Nation, 226.

${ }^{118}$ Fox, Culture of Consumption, xii.
} 
ways that they had not before. As the primary purveyors of this new culture of consumption, department stores found themselves at the nexus of concerns not just about consumerism, but also about gender. 


\section{CHAPTER III}

\section{CONFLICTING VALUES, THE DEPARTMENT STORE, AND ITS SALESWOMEN}

In the 1880 s, women made up a very small percentage of the department store workforce, but by the turn-of-the-century, they made up a majority of the sales staff in most stores. This was part of a larger movement of working-class women moving into wage-work necessitated by the high cost of living and low wages paid to many workingclass, male breadwinners. The increasing presence of women in the department store generated conflict, particularly between the predominantly female working-class saleswomen and the mostly middle-class customers and members of management. As these working women navigated the heterosocial landscape of the department store, they also found themselves the subject of debate about the moral questions raised when women entered the public space.

\section{Women in Public and Increased Labor Participation}

For the working class, modern urban life created major changes in family roles and expectations. In her classic, Out to Work, Alice Kessler-Harris offers a layered explanation for women's increased participation in the workforce. She stresses that the women who went to work for the first time in the late 1800s and early 1900s were not a homogenous group, yet they shared some common circumstances. For example, inflation in the late nineteenth century resulted in a rising cost of living for all Americans, forcing some families to send children or wives to work. Although the vast majority of married 
working-class women still did not work outside the home, other female members of the family were entering public wage work in increasing numbers. ${ }^{119}$ Kessler-Harris explains how working-class, urban families found it more difficult than other groups to adapt to these circumstances because city life necessitated the purchase of basic consumer goods that had previously been manufactured at home. Purchasing these essentials required family incomes that could often not be furnished by fathers alone, pushing many women, particularly un-married daughters into the labor market. ${ }^{120}$ Those families who might normally have been able to avoid child or female labor sometimes were forced into those arrangements because of a family crisis. An unexpected job-loss, injury, wage cut, or reduction in hours could wreak havoc on a tight family budget. ${ }^{121}$ Kessler-Harris' recognition of the commonalities between working women, as well as the unique circumstances of peripheral groups, has helped subsequent historians to recognize the diversity of experience of women workers of the time period.

Census figures used by Kessler-Harris reveal how the economic pressures of the time impacted the female workforce nationally. For example, in 1890, about 3.3 percent of married women worked outside the home, while in 1920, the number had risen to nine percent. Birth rates had dropped and female life expectancy had risen in the preceding decades, meaning that many older women could expect to have to support themselves for several years in the absence of working children or a spouse. ${ }^{122}$ Married saleswomen made up an increasing minority of the workforce in the decades before and after the turnof-the-century. Data from 1924 shows that 20.7 percent of retail workers in Illinois were

\footnotetext{
${ }^{119}$ Kessler-Harris, Out to Work, 121.

${ }^{120}$ Ibid, 119.

${ }^{121}$ Ibid, 121.

${ }^{122}$ Ibid, 110.
} 
married, while an additional 21.2 percent were widowed, divorced, or separated. ${ }^{123}$

Despite their increased participation, married women still did not dominate the workforce and when they did work for wages they tended to be employed as poorly paid, domestic day workers. ${ }^{124}$ Laboring in the public workforce was largely still the domain of unmarried women.

Like the typical department store clerk, most women in the workforce were young and single. ${ }^{125}$ Their presence in the organized workforce had been rapidly increasing as the nation industrialized. While perhaps half of teenage girls worked outside the home before the Civil War, over three-quarters did so by 1890, feeling compelled to help ease the financial difficulties of their working-class families. ${ }^{126}$ In Chicago, the proportion of women entering the workforce between 1880 and 1930 was nearly three times greater than the national average. 67 percent of single women and 32 percent of all females in the city were employed by $1930 .^{127}$ The large numbers of women entering the workforce during this time period challenged traditional divisions between male and female spheres. In her book Cheap Amusements, Kathy Peiss describes nineteenth century women as largely moving within a homosocial world, dominated by women and largely restricted to the home. Toward the turn of the century, however, as women became increasingly involved in employment, education, and politics, they were drawn into the public male sphere. ${ }^{128}$ Howard Chudacoff describes this integration as an extension of Progressive ideals. The reform-minded middle-class expected fathers to play an active

\footnotetext{
${ }^{123}$ Benson, Counter Cultures, Appendix F.

${ }^{124}$ Kyle E. Ciani, "Hidden Laborers: Female Day Workers in Detroit, 1870-1920." Journal of the Gilded Age and Progressive Era 4, no. 1 (January 2005): 23-51.

${ }^{125}$ Peiss, Cheap Amusements, 5.

${ }^{126}$ Kessler-Harris, Out to Work, 121.

${ }^{127}$ Meyerowitz, Women Adrift, 5.

${ }^{128}$ Peiss, Cheap Amusements, 6-7.
} 
role in family life at home and by extension in the public life of the community. Familyoriented recreation, such as Chicago's renowned parks and museums, and heterosocial, white-collar work environments, like the city's great department stores, helped to undermine the bachelor culture which had previously dominated public city life. ${ }^{129}$ However, this process was gradual and remnants of the public male sphere were still evident. This was surely the case in Chicago, a city that Lisa Fine describes as gritty and unabashedly masculine. The city's rapid growth and increasing national prominence made it ambitious, "hard and impersonal." It was a "world of men" except for the downtown department stores and upscale hotels and restaurants. ${ }^{130}$

As a heterosocial public culture emerged, significant conflict arose as young women embraced their new freedom, but risked condemnation for violating Victorian values which had not yet receded. ${ }^{131}$ For women of all social classes, entering the public space in new ways could be a risky experience. Women customarily had only circulated in public to converse with neighbors, visit parks, and attend church. ${ }^{132}$ Therefore, when more women began to engage in work outside the home, they entered a public sphere that was dominated by males. From a social standpoint, this could put a woman's reputation at risk as the society at large associated women moving freely in these public spaces with prostitution. Sharon Wood argues that both working and middle-class women were well aware that their safety and reputation could not be guaranteed when they ventured out to take these new positions. Conversely, a man could freely move about the city without

\footnotetext{
${ }^{129}$ Howard P. Chudacoff, The Age of the Bachelor: Creating an American Subculture (Princeton, N.J.: Princeton University Press, 1999), 17.

${ }^{130}$ Fine, Souls of the Skyscraper, 5-6.

${ }_{131}^{131}$ Peiss, Cheap Amusements, 6-7.

${ }^{132}$ Ibid, 33.
} 
risking his standing in the community or engendering scrutiny of his private activities. ${ }^{133}$ While Wood focused on this double-standard in Davenport, Iowa, women in Chicago undoubtedly had similar concerns. As urbanization increased during the period, larger numbers of women found themselves drawn to this complex public space.

During the Gilded Age, the growing number of urban women needing or desiring work outside the home also created challenges to traditional or older views of women in the public space. ${ }^{134}$ In Souls of the Skyscraper, Lisa Fine notes that men were accustomed to a public workplace that functioned as an exclusively male sphere. When women began to enter that sphere as clerks and saleswomen, many male workers found it unsettling. Males could not associate with female co-workers in the ways that they once did with male co-workers, nor did they feel free to speak and act as they used to in an allmale setting. ${ }^{135}$ This is not to say that men and women developed rival spheres within the workplace, misunderstanding and acting with hostility toward each other. Indeed the new heterosocial working environments were a reflection of the urban world outside the workplace where men and women would informally mingle.

Along with concern over women entering traditionally male spaces, there was also general concern that women would be exposed to people of different social classes, age groups, and ethnicities in the workplace. Husbands and fathers would lose some patriarchal control over whom their wives and daughters interacted with on a daily basis. ${ }^{136}$ Accordingly, older generations feared that women entering the workplace would destroy the structure of the family. They surmised that if women ventured beyond

\footnotetext{
${ }^{133}$ Sharon E. Wood, The Freedom of the Streets: Work, Citizenship, and Sexuality in a Gilded Age City (Chapel Hill: University of North Carolina Press, 2005) 7.

${ }^{134}$ Ibid, 7.

${ }^{135}$ Fine, Souls of the Skyscraper, 17.

${ }^{136}$ Wood, Freedom of the Streets, 18.
} 
the confines of home that their exposure to the masculine public space would render them unfit or unwilling to re-enter domestic life. ${ }^{137}$ This view was particularly widespread among immigrant parents who often held traditional views rooted in peasant culture, giving parents, particularly fathers, power over their daughters' labor, social life, and romantic relationships. ${ }^{138}$ Single working women who failed to marry would be, in historian Carolyn Strange's words, denying society a fit "guardian of future generations." 139

Unlike this new generation of working women, previous generations of women were mainly isolated in the home, where never-ending household duties performed at irregular hours kept them sequestered. This isolation took on different forms for different racial groups and social classes. Working class, African American, and Latino women were often left with few choices beyond domestic work and were therefore tethered to the home of their employers. ${ }^{140}$ Middle-class women avoided entering the workforce because they could afford not to, but also because they felt a socially prescribed, deep moral conviction that their absence would be neglectful to their families. For this reason, they encouraged working-class women to pursue wage-work from home if employment was necessary. ${ }^{141}$ These pleas were often ignored as greater employment opportunities opened up for working-class, white women (minority groups would continue to see limited job opportunities for some time). As more women began to work outside the

\footnotetext{
${ }^{137}$ Carolyn Strange, Toronto's Girl Problem: The Perils and Pleasures of the City, 1880-1930 (Toronto; Buffalo: University of Toronto Press, 1995), 28.

${ }^{138}$ Mary E. Odem, Delinquent Daughters: Protecting and Policing Adolescent Female Sexuality in the United States, 1885-1920. Gender \& American Culture (Chapel Hill: University of North Carolina Press, 1995), 159.

${ }^{139}$ Strange, Toronto's Girl Problem, 28.

${ }^{140}$ Peiss, Cheap Amusements, 35.; Nancy Woloch, Women and the American Experience, Fourth Edition (New York: McGraw Hill, 2006), 393, 396.

${ }^{141}$ Kessler-Harris, Out to Work, 90.
} 
domestic sphere, their fixed working hours allowed them to designate time for leisure outside the home. This gave women, particularly single women, the opportunity to participate in the increasing number of commercial amusements that ensured that they spent even more time out in public and with men. ${ }^{142}$ These activities pushed the boundaries of what middle-class culture and traditional working-class parents viewed as acceptable, but women relished them as sources of freedom and pleasure. ${ }^{143}$ It was not as though working women ignored or were unaware of the dangers that their public presence could bring about, but they felt that they were able to control the risks with their own savvy and the protection of peers. ${ }^{144}$ For instance, in Women and the City, Sarah Deutsch explains that laboring women worked to create their own "moral geographies," distinguishing between places where they felt safe and unsafe. ${ }^{145}$

Members of the working class placed a huge priority on their own independence and frequently resented the "protection" offered to them by family or the middle-class. ${ }^{146}$ For example, middle-class reformers frequently pushed for minimum wages in the department store because they viewed low wages as a cause of vice. While some working-class women may have appreciated this effort, others did not. They resented the implication that their moral behavior was connected to their employment status and public presence. One woman in testimony before a state hearing stated that saleswomen were "pretty hot because of all of the criticism of them and the talk about immorality." She fumed, "these so-called social workers who make breaks about the poor

\footnotetext{
${ }^{142}$ Peiss, Cheap Amusements, 35.

143 Ibid, 6.

${ }^{144}$ Sarah Deutsch, Women and the City: Gender, Space, and Power in Boston, 1870-1940 (New York: Oxford University Press, 2000) 114.

145 Ibid, 79.

${ }^{146}$ Ibid, 113.
} 
downtrodden shop girl mostly do not know what they are talking about."147 Her obvious irritation implies that this issue was probably not the only one over which working women and middle-class reformers clashed.

Public obsession and fear over prostitution motivated both those who supported and opposed greater female labor participation. Proponents of working women argued that women who were denied other job opportunities or given only low paying ones would be driven into prostitution, while opponents argued that leaving the protection of the home would allow women to fall prey to brothel owners. ${ }^{148}$ This fear was rooted in the idea that wage-earning women separated themselves from the traditional obligations of marriage in which a woman exchanged sex and domestic labor for economic support from her husband. If a woman was not dependent on this exchange, traditionalists feared that she would feel free to seek sexual pleasure elsewhere. Thus, a woman who worked in the emerging female job market risked her reputation by moving within a physical space where she might encounter prostitution and upset the traditional obligations of marital exchange. ${ }^{149}$ As a consequence, many middle-class reformers rationalized that working women were better off in environments that mimicked the home, such as domestic service. The values instilled at these jobs were also seen to be more useful for women when they left their jobs to work as homemakers. The result was a deeply rooted gender-based division of labor within the job market. ${ }^{150}$

\footnotetext{
147 "Shopgirl Fights Minimum Wages," Chicago Daily Tribune, Jan 10, 1915, 1.

${ }^{148}$ Wood, Freedom of the Streets, 8.

149 Ibid, 16.

${ }^{150}$ Kessler-Harris, Out to Work, 128.
} 
With more young women circulating in public as they worked, the middle-class in particular feared that visible prostitution in the city would "pollute" the rest of society" Yet, when women did become prostitutes, most women of all social backgrounds saw them as distinctive, degraded class. Middle and working-class women who did not prostitute universally rejected prostitutes from their social ranks. ${ }^{152}$ The social stigma attached to prostitution made women think twice about any activity that might associate them with its practice, including working outside traditional settings. However, there were some reformers who rejected the idea that women who became prostitutes were “fallen women" and morally corrupt. In her influential 1890 investigation of New York working women, Alice Woodbridge concluded that working women who turned to prostitution to help their families economically were "heroic," willing to sacrifice themselves for the good of others. ${ }^{153}$ Moreover, middle-class social workers who investigated the factors that drew women into prostitution found themselves more sympathetic. Many members of the middle-class assumed that women entered prostitution primary under economic duress, but their investigations revealed that working conditions also played a major role. ${ }^{154}$ Investigators seemed especially concerned with the crowded conditions in factories and boarding houses, which they felt exposed young women to crude and immoral behaviors. This exposure, they surmised, might cause a woman to slide into prostitution. ${ }^{155}$

\footnotetext{
${ }^{151}$ Meyerowitz, Women Adrift, 61.

${ }^{152}$ Wood, Freedom of the Streets, 28.

${ }^{153}$ Cited in Lara Vapnek, Breadwinners: Working Women and Economic Independence, 1865-1920. (Urbana: University of Illinois Press, 2009) 81.

${ }^{154}$ Kessler-Harris, Out to Work, 101.

155 Ibid, 102.
} 
Despite the heavy public concern over the issue, very few working women chose or were forced into prostitution. Instead, many working women sought out jobs that they believed would help them financially, but would also bring them respect in their communities. Their perceptions were formed by their interactions in the workplace, public opinion, and coverage of the issue by the media. ${ }^{156}$ Working-class women absorbed many of the prevailing views about employment and immorality, but their views varied slightly from those of the middle-class. While the middle-class associated any work outside of a domestic setting as dangerous, working-class women typically applied this assumption to domestic labor and factory work. Some working-class women believed that certain occupations attracted "nice" girls, notably department store clerking, while factory workers were often viewed as immoral. This presumption may have been rooted in the fact that department store clerks looked and acted more like their middleclass patrons. Despite the fact that factory workers and department store clerks earned similar wages, some historians, such as Alice Kessler-Harris, have argued that they spent their incomes in different ways. She states that clerks often sacrificed their food budgets in order to spend more of their income on clothing and desirable apartments. Factory workers spent their money on more nourishing food and cared less about their physical appearance. ${ }^{157}$ However, this point in particular has been challenged by other historians, including Peiss. ${ }^{158}$ The social prestige attached to some jobs over others created competition for jobs among women, even when the total number of jobs available to women was adequate to meet demand. ${ }^{159}$

\footnotetext{
${ }^{156}$ Fine, Souls of the Skyscraper, 50.

${ }^{157}$ Kessler-Harris, Out to Work, 135.

${ }^{158}$ Peiss, Cheap Amusements, 72

${ }^{159}$ Kessler-Harris, Out to Work, 140.
} 
Opposition to increased female employment sometimes arose from economic anxieties. These opponents contended that female laborers, even those working for low wages, were harmful to employment opportunities for men. They argued that most women entered the workforce for economic comfort, not out of need. Because their wages were lower than those paid to working-class men, these women drove down wages for both men and for women who needed work out of necessity. ${ }^{160}$ These lower wages were a reflection of the predominant social obligations of both men and women. At best, a woman's wages were expected to provide for her independence at a subsistence level and at worst, her wages were viewed as a supplement to the family income.

Differentiated wage expectations between the genders also helped to ensure that males earned a living wage, which was accepted as necessary to support a family. No consideration was given to women who either needed a higher income to support children or merely wanted a better standard of living. ${ }^{161}$ In reality, as previously discussed, working-class women were flooding the work-force out of need created by a changing industrial society. Interestingly, some business leaders opposed equal pay not because of its potential to threat to males, but because of its potential harm to females. For example, Random Olds, owner of REO Motor Company, was a staunch opponent of equal pay for men and women not because he opposed working women, but because he believed that it would limit their numbers in the labor force. If wages for men and women were equal, Olds believed, men would be usually given the advantage and women would have few opportunities for employment. ${ }^{162}$

\footnotetext{
${ }^{160} \mathrm{Ibid}, 99$.

${ }^{161}$ Enstad, Ladies of Labor, 99.

${ }^{162}$ Lisa M. Fine, The Story of Reo Joe: Work, Kin, and Community in Autotown, U.S.A. (Philadelphia, PA: Temple University Press, 2004), 40-41.
} 


\section{Rise of the Female Clerk}

During the Gilded Age, women certainly did have relatively narrow employment opportunities, but the growing consumer culture was beginning to change that. For white, native-born women, department stores were creating new opportunities. In the 1880 s, women made up a very small percentage of the department store workforce. ${ }^{163}$ The first women employed in the stores were wanted for departments, such as lingerie, where female customers might be uncomfortable with a male salesman. ${ }^{164}$ However, as noted in the previous chapter, the size of department stores soon increased because stores were doing more than just selling merchandise, they were creating an experience. Department stores relied on repeat customers who would speak well of the store, pay their bills on time, and return to make purchases for years to come. Creating this goodwill meant that stores had to make the shopping experience as enjoyable and luxurious as possible. ${ }^{165}$ As William Leach describes it, the principal focus of the emerging consumer culture was "acquisition and consumption as a means of achieving happiness" and the department store was the primary means of achieving that end. ${ }^{166}$ Customer services expanded accordingly and the cost of employing a mostly male staff in the large stores ballooned. In response, store management began to slowly integrate more and more female employees into the workforce. ${ }^{167}$

In the first decade of the twentieth century, Chicago department stores started hiring a larger number of women. By the end of that decade, they made up a significant majority of the workforce, although men also continued to work as clerks in some

\footnotetext{
163 Peiss, Cheap Amusements, 15.

164 Malino, "Faces Across the Counter," 114.

${ }^{165}$ Benson, Counter Cultures, 75.

${ }^{166}$ Leach, Land of Desire, 3.

${ }^{167}$ Malino, "Faces Across the Counter," 30.
} 
departments. ${ }^{168}$ Given the social norms of the time, it was expected that women would earn lower wages than men in similar positions. ${ }^{169}$ Saleswomen earned at least $50 \%$ less than salesmen per week, making their employment a smart financial move for the house. ${ }^{170}$ Women also offered a more stable workforce. Jobs open to women outside of department store work were limited, so women were less likely to leave retail work for another job, unlike men who could find jobs in most sectors. ${ }^{171}$ It was also common for stores to hire more women in an attempt to make female shoppers more comfortable. They were perceived to possess social skills that made them more agreeable and wellmannered to other women than male clerks. ${ }^{172}$

The typical saleswoman came from a working-class background and in urban areas such as Chicago, saleswomen were overwhelmingly white and native-born. ${ }^{173}$ Because their duties required basic reading, writing, and mathematics skills, store clerks were formally educated, although most did not graduate from secondary school. ${ }^{174} \mathrm{~A}$ store manager in a 1907 Chicago Tribune article stated clerks "must be educated in the ordinary sense of the term, and at the same time they must be well dressed, must have tact, and must be peculiarly gifted in the way of dealing with other people."175 This description would certainly have fit the middle-class, but poor wages, hours, and working conditions deterred many single, middle-class women from department store work at the

\footnotetext{
${ }^{168}$ Hollis W. Field, "Women Fill Up Counters: Sell More Goods Than Men," Chicago Daily Tribune, January, 19, 1908, E5.

${ }^{169}$ Malino, "Faces Across the Counter," 30.

${ }^{170}$ Field, "Women Fill Up Counters," E5

171 Ibid, E5.

172 Malino, "Faces Across the Counter," 35.

173 Benson, Counter Cultures, 209.

${ }^{174}$ Malino, "Faces Across the Counter," 51.

175 Raymond, "Saleswomen are Well Educated," Chicago Daily Tribune, Jul 5, 1907, 1.
} 
turn-of-the-century. ${ }^{176}$ On average, saleswomen were slightly older than other female workers. This was probably because clerks received increased compensation with age, regardless of their experience level. Older clerks were typically also praised for the dignity and professionalism that they brought to the job. ${ }^{177}$

Despite its increasing popularity as a profession, most women considered working in a department store to be a temporary bridge between childhood and married life. Joining the workforce for a few years was a way to gain new experiences and earn extra money before marriage. Wages could provide women with a degree of independence as some workers used their income to challenge traditional family dynamics. Often young women who entered the workforce felt less beholden to their parents and tried to use their wages to re-negotiate their domestic responsibilities at home. ${ }^{178}$ Compared to women in other professions, saleswomen were more likely to live apart from family, although most continued to live with family members. ${ }^{179}$ In 1908 , for instance, over 20 percent of all Chicago department store clerks lived independently. ${ }^{180}$

On the other hand, while they faced less control at home, women were often vulnerable to exploitation at work. ${ }^{181}$ Severe fines for infractions, unsanitary employee facilities, uncompensated overtime, and sexual harassment by male co-workers were common complaints among saleswomen. ${ }^{182}$ The negative publicity that these practices generated with the general public made them less common over time. This is evidenced by questions asked of department store managers at an Illinois State Senate Committee

${ }^{176}$ Benson, Counter Cultures, 128.

${ }^{177}$ Ibid, 201.

${ }^{178}$ Vapnek, Breadwinners, 55.

${ }^{179}$ Benson, Counter Cultures, 206.

${ }^{180}$ Ibid, Appendix G.

${ }^{181}$ Vapnek, Breadwinners, 55.

182 Ibid, 81. 
hearing in 1913. While most managers were asked questions about fines and relayed that they had abandoned the practice, one Chicago merchant admitted that he had not.

Edward Hillman of the Hillman Company refused to use the term "fine," but described how he docked the pay of clerks for lost packages or late arrivals. ${ }^{183}$ As part of the same testimony, Mr. Hillman was asked about how the store handled floor managers who sexually harassed female employees. Hillman responded that they were fired and that other stores were informed of the inappropriate behavior so as to avoid hiring the men in the future. His language implied that this was a somewhat regular occurrence on State Street. $^{184}$

For most women experience in the department store workforce was brief.

Unfortunately, this norm meant that women who wanted to avoid or delay marriage found it difficult to advance within a system that assumed that they would be out of the workforce in a few short years. This assumption also had a serious impact on a woman's earning potential and store operations. During times of prosperity, city’s department stores found it difficult to maintain the predominantly female workforce because most women saw their employment with the firms as temporary, lasting only until they married. A Chicago Tribune article from 1901 describes how when the economy was growing and wages were rising, many men found that they could afford to marry earlier. As a result, women had shorter courtships and engagements, pulling them from the workforce prematurely. In some cases this trend occurred so rapidly and in such great numbers that department stores were faced with severe staffing shortages. The number of positions available then exceeded the supply of qualified workers. Girls of school-age

\footnotetext{
183 Report of the Senate Vice Committee Created Under the Authority of 48th General Assembly, (Chicago: State of Illinois, 1916), 220.

${ }^{184}$ Ibid, 219.
} 
were also pulled from the workforce since in a strong economic environment, their parents often did not have the need for their income and could afford to send them to high school. $^{185}$

Out of desperation, some stores had to hire more salesmen and, as a result, the labor costs of the stores increased. An alternative was to advertise positions in rural areas, hoping to attract young women who would relocate. In 1901, the problem was so severe that the Loop stores, those located in Chicago's downtown retail hub, lost twentyfive percent of their workforce heading into the holiday shopping season. One manager told the Tribune that this was because "they prefer wifehood to clerkships."186 This may or may not have been true, but it is certainly an over-simplification of the situation. Many women may have wanted to keep their jobs and get married, but social pressures kept them from doing so. Rationalizing this decision would have been particularly difficult for women during times when economic prosperity made their work outside of the home less of an economic necessity. In these ways, the expectations of gender and class that drove many of the decisions of individual women were also having an impact on the department store as a business and cultural institution.

The Department Store Reflects the Middle-Class

Like many public institutions, department stores were reflective of the values and priorities of their patrons. In the nineteenth century, the middle-class came to view the family as a private refuge from the hectic outside world. Over time, material goods became an important factor in creating that refuge and demonstrating a family's

\footnotetext{
185 "Stores Robbed By Cupid," Chicago Daily Tribune, Dec 02, 1901, 1.

${ }^{186}$ Ibid, 1.
} 
respectability. ${ }^{187}$ As the middle-class gradually accepted the new culture of consumption, the department store became an important force for determining and disseminating Victorian values. As Elaine Abelson argues, the department store thus found itself situated at the intersection of commerce, gender, and class expectations. ${ }^{188}$ Department stores balanced these expectations carefully. On the one hand, it was in the interest of the store to promote the idea of traditional female domesticity and family respectability. Women's roles as the creators of safe and nurturing home environments could be manipulated to encourage their consumption of consumer goods as a means to realize that ideal. Moreover, Victorian women wanted to make purchases that that they believed improved the comfort and respectability of their families. Encouraging consumption as a projection of social class and respectability was equally positive for business. If middleclass families believed that a piano or set of china was a symbol not of their wealth, but of their respectability, they would be more likely to make the purchase. On the other hand, as businesses, department stores also needed to encourage future purchases by promoting change and innovation. In creating and marketing new styles and fashions, stores created a continual demand for new products and new purchases. Stores promoted these changes as "modern" and made it their goal to educate their middle-class customers about them.

In promoting both Victorian ideals of respectability and modern consumerist values, department stores successfully reconciled what seemed to be contradictory value systems: the continual consumption promoted by commercial interests and the financial

\footnotetext{
${ }^{187}$ Abelson, When Ladies, 27-28.

${ }^{188}$ Ibid, 4.
} 
prudence respected by the middle-class. ${ }^{189}$ Sarah Smith Malino argues that store owners were motivated to promote this reconciliation not only because it was good for business, but because they believed it was good for society. Department stores owners saw themselves not only as disseminators of good taste, but also of greater equality and moral living. Advertising from large stores promoted the idea that people could improve their social standing through purchases. For example, an advertisement for Chas. A. Stevens \& Bothers, "Daylight Basement," a department for working-class shoppers, advertised "high character garments," appealing to the aspirations of less affluent shoppers and making those goods accessible to them. ${ }^{190}$ Stores could help customers make wise choices about such purchases and surround themselves with goods which John Wanamaker claimed led "to higher thinking and to higher learning."191 With greater numbers of middle-class women making shopping a duty and a pastime and workingclass women making occasional department store purchases, these efforts were reaching a large audience.

The wide-scale employment of domestic help and the conveniences of modern household technology freed up a good deal of time for many middle-class women. Shopping was a way to fulfill a traditional family duty assigned to women, albeit an increasingly entertaining one, and fill a woman's day. ${ }^{192}$ The cleanliness, comfort, and diversion of the stores made middle-class women feel at home and made shopping what Abelson identifies as a "quasi career."193 Victorian women also found that department stores enabled them to spend a considerable amount of time downtown and in public

\footnotetext{
${ }^{189}$ Ibid, 53.

190 "Display Ad 86 -- no Title." Chicago Daily Tribune), Oct 10, 1920, E12.

${ }^{191}$ Malino, "Faces Across the Counter," 13.

192 Benson, Counter Cultures, 77.

193 Abelson, When Ladies, 41.
} 
without risking social judgment. At a time when many public-spaces, such as movie theaters and dance halls, were considered inappropriate and even immoral by middleclass standards, department stores were a notable exception. ${ }^{194}$

The physical layout of the store reflected the needs and desires of its middle-class clientele. Upon entering the department store, women were surrounded by goods that symbolized their social standing and aspirations. While in reality the merchandise on display certainly encompassed goods far greater than middle-class families could reasonably obtain, women felt that those items were within their reach and reflected their standard of living. ${ }^{195}$ Department stores promoted this thinking by playing into the "democratization of desire," a phrase used by William Leach to describe the belief that all people could aspire to and envision themselves in particular lifestyle. ${ }^{196}$ Stores were designed to help women picture the goods in their own households and inspire purchases. For example, stores created model rooms and homes on the sales floor to show off their merchandise and attract onlookers. These idealized creations were often more luxurious than most customers could afford, but they appealed to the Victorian priority of domestic comfort. ${ }^{197}$ Similarly, store owners hoped that women would make their store a second home. Store tea rooms, lounges, and shopping areas provided a place where women could socialize and relax without the stresses of entertaining in their own home or minding children. Free from the worries of maintaining tidiness, hospitality, and provisions, women were able to spend their time as they wished within the store and

\footnotetext{
${ }^{194}$ Benson, Counter Cultures, 84.

195 Abelson, When Ladies, 46.

${ }^{196}$ Leach, Land of Desire, 6.

${ }^{197}$ Abelson, When Ladies, 52.
} 
hopefully, make more purchases. ${ }^{198}$ These amenities placed women in domestic settings within the public space and served to reconcile the new consumer culture with Victorian values. Retail spaces were sometimes laid out to appear more intimate, more like small, boutique shops, while other stores tried to create an indoor market of "pavilions" for grocery items. Both designs were built with the middle-class in mind and were intended to increase comfort and therefore spending. ${ }^{199}$ For decades, store managers believed that if they helped customers feel like guests in a middle-class home, that shoppers would lower their guard and be more open to buying. ${ }^{200}$

Store improvements were not only initiated by owners, but were often demanded by the middle-class clientele themselves. As the discretionary income of middle-class families grew, stores were faced with an increasingly competitive market. Victorian households had better standards of living and greater expectations than generations before. Store services were one way to appeal to potential customers, but the middleclass also sought to have their developing ideas of good taste and manners affirmed. The middle-class had developed their own opinions about proper dress, furnishings, and house-wares which the department stores were ready to supply. Stores also began to promote middle-class consumption as the "correct" way to purchase and use items.

Unfortunately, this mentality created problems for both customers and stores. Patrons' expectations and ideas about consumption often exceeded their incomes. Stores were actively promoting a level of consumption as proper that the working-class could not possibly afford. ${ }^{201}$ Therefore, in aiming to appeal to the middle-class, department

\footnotetext{
198 Ibid, 53.

${ }^{199}$ Leach, Land of Desire, 78-79.

${ }^{200}$ Benson, Counter Cultures, 83.

201 Ibid, 22.
} 
stores could alienate working-class shoppers. Bargain basements and discount departments were created to appeal to the working-class, but they were often outfitted with cheaply-made goods and less impressive decoration. As a result, many workingclass shoppers continued to make purchases in smaller, neighborhood stores or from street vendors. ${ }^{202}$ Store management also discovered problems with the services that they had created to appeal to middle-class customers. As public institutions, all customers had the opportunity to use in-store services. Regardless of how little they spent, customers felt entitled to use store delivery, credit, and amenities, threatening store profit margins. In effect, all customers had to be treated as respectable customers and early stores made few attempts to alter customer demands. ${ }^{203}$ In the end, stores considered this policy a smart business decision. Whether a customer was solidly middle-class or not, they had a degree of discretionary income — better that it be spent within their store than elsewhere. $^{204}$

\section{Middle-Class Managers}

The middle-class made up the bulk of the department store's customers, but also claimed most of its managers among their ranks. The management system in a department store was complex and changed over time, but generally included upper-level management that operated on a store-wide level, floor managers or department managers who monitored the work of clerks in one or more departments, and buyers who purchased goods and educated clerks about the merchandise. The executives of upper-level management often had little knowledge of their staff and deferred to their floor managers when dealing with individual employees. This could alienate clerks and tested their

\footnotetext{
202 Ibid, 78.

203 Ibid, 22.

${ }^{204}$ Ibid, 77.
} 
loyalty to the store as an institution. ${ }^{205}$ Elaine Abelson describes the relationship as similar to that in a factory, "impersonal, hierarchical, and class bound."206

By and large, most floor managers were middle-class males. However, from early on, department stores did employ small numbers of women as lower-level managers. For example, in 1870, all eight of Macy's stores listed floor managers were women. It should be noted, though, that executives still played a direct role in day to day store operations at this time and that group was overwhelmingly male. ${ }^{207}$ When employed as floor managers, women were given the same authority and responsibility as men in the same position, but were paid less. ${ }^{208}$ Moreover, department stores did not actively seek out female managers and male managers were likely to recommend other males as new hires, but stores did not appear to actively reject female candidates for promotion. ${ }^{209}$ According to census data in 1920, one to two percent of all women working in department stores were floor managers and a similar number were working as buyers. ${ }^{210}$ For women who sought work as managers, business experience was essential and a college education was preferred. ${ }^{211}$ Women could have already attained this level of education or they could have pursued it after employment with the store. Some stores offered tuition assistance to employees who wished to take university courses. ${ }^{212}$ In her dissertation on female executives at Macy's and Filene's, Judy Miler concludes that the

\footnotetext{
205 Abelson, When Ladies, 97.

${ }^{206}$ Ibid, 99.

${ }^{207}$ Malino, "Faces Across the Counter," 115.

${ }^{208}$ Ibid, 119.

${ }^{209}$ Ibid, 215.

${ }^{210}$ Malino, "Faces Across the Counter," 217-218.

${ }^{211}$ Judy K. Miler, "Hidden Within: Women's Managerial Role in the Rise and Development of Two Major U.S. Department Stores, 1870-1920." (Ph.D., University of Tennessee, Knoxville, 1990), 131.

${ }^{212}$ Benson, Counter Cultures, 161.
} 
majority of women who rose to upper-management in stores did so from within the organization. $^{213}$

Protocols for floor managers seem to have been loosely defined during the early years of department stores. An undated Marshall Fields' pamphlet from the late 1800s, compiled advice for new floormen drawn from a survey of twenty-two experienced managers. Floormen were encouraged to treat their employees with respect and kindness, while avoiding excessive familiarity. They were expected to oversee the work of the sales staff, but also to supplement the instruction of store-wide education programs. ${ }^{214}$ Typically, department stores did not allow saleswomen much input into the content of their employee training programs. This allowed the store to control the development of the employee's skills, but also discouraged any tactics employed by the saleswoman that the store considered unacceptable. ${ }^{215}$ The pamphlet makes it clear that managers were held to the same or higher standards of behavior in demeanor and dress than that expected of saleswomen. When rebuke of a saleswoman was required, managers were encouraged to apply the "Golden Rule" to their conversation and always avoid public embarrassment of the staff member. ${ }^{216}$ While there are many general principles included in the pamphlet to guide floor managers, there are no specific rules outlined for managers to follow. This implies that early on floor managers were allowed to exercise a good deal of personal discretion in the oversight of their department(s) and likely had the freedom to pursue what they saw as the most effective management style.

\footnotetext{
213 Miler, "Hidden Within," 281.

214 “Floorman's Manual,” 1922, Box 18002, “Marshall Field and Company Records,” Chicago Historical Society, Chicago, 1.

${ }^{215}$ Benson, Counter Cultures, 141.

216 "Floorman's Manual," 2.
} 
In 1901, the Chicago Tribune published an article detailing a day in the working life of a male State Street manager, Franz Bauer. Mr. Bauer rose to the position of superintendent, a position which oversaw floor managers and saleswomen, by slowly working his way up the store hierarchy. The article implies that Bauer was well-paid at twenty-five dollars a week, but that he was required to put in long hours, arriving before the sales staff and leaving only after the last remaining employee. He spent time each day reviewing the performance of saleswomen based on a ratio of their salary paid to their daily sales. The article details an exchange between Mr. Bauer and a clerk in which he rather callously informs her that she will need to improve her sales numbers. If she fails to do so, her salary will be reduced or she could be fired. He offers no advice as to how to improve her performance. The article goes on to describe how the superintendent proceeds to have similar exchanges with numerous store employees in a gruff, but professional manner. The author seems to praise Mr. Bauer's demeanor and makes no criticism of the lack of constructive feedback that he offers employees. ${ }^{217}$ This seems to imply that this style of management was accepted as the norm among department store managers of the time.

While clerks may have had occasional interaction with an upper-level manager, such as Mr. Bauer, they would have had daily contact with floor managers. Floor managers were the level of management who often had some of the most sensitive and antagonistic relationships with saleswomen because their job involved critiquing the selling skill of the clerk, the hallmark of her job. ${ }^{218}$ Generally speaking, saleswomen

\footnotetext{
217 "A Day With a Wage Earner No.9 the Department Store Superintendent," Chicago Daily Tribune, Jul. 24, 1901, 4.

${ }^{218}$ There were numerous similar positions that overlap with the position of the floor manager, including floorwalkers, department managers, and sometimes "buyers." Different terms were used during different
} 
were open to advice from buyers because their training regarding merchandise was unlikely to include comment on a clerks' personal characteristics. Conversely, the education on salesmanship from upper-level management and floor managers could be viewed as patronizing or insulting. ${ }^{219}$ Benson identifies the organization of salespeople as "by far the most persistent and troubling problem of department store managers." 220

Managers commonly used punitive measures to try and control the behavior of sales clerks. Undercover investigations for theft, fines for tardiness or sales errors, and public admonishment of employees in front of other staff members were commonplace. $^{221}$ This could be seen as evidence of conflicting values between middleclass managers, prioritizing sound finances and self-discipline, and working-class clerks, asserting their right to self-respect and independence in the workplace. Despite displeasure from the public, the presence of store protocols, and criticism from trade journals regarding these approaches, they remained routine in some stores until the 1930s. ${ }^{222}$ Saleswomen often pushed back against these tactics by management by flagrantly violating the rules or joining forces to support an employee whom they felt was unfairly punished. This was a result of a strong workplace culture fostered among saleswomen that was a frustration to many managers, but also a necessity because it regulated interpersonal conflicts between employees. ${ }^{223}$ The transition away from this heavy-handed approach seems to be evident by the time Marshall Fields' published its 1922 Floorman's Manual. The manual stresses that while adherence to the rules was

historical periods and by different stores. I use the term "floor managers" to denote managers of various titles who worked on the sales floor and oversaw and interacted with clerks.

${ }^{219}$ Benson, Counter Cultures, 253-254.

${ }^{220} \mathrm{Ibid}, 124$.

${ }^{221}$ Ibid, 138.

${ }^{222}$ Ibid, 138 .

${ }^{223}$ Ibid, 256. 
important, that reprimand should be conducted in a way in which the employee feels like she is part of improving the store rather than simply being admonished. Managers were supposed to discuss infractions with the saleswoman privately to avoid embarrassing her in front of other employees. ${ }^{224}$ When reprimands were necessary, floormen were encouraged to provide the employee with an extra pleasantry upon their next meeting to ease any ill will. ${ }^{225}$

The specificity of the protocols in the 1922 manual suggest that floormen at that time had far less autonomy in their oversight of saleswomen compared with earlier generations of floor managers and that greater concern was being given for the cultivation of a positive working environment for female employees by upper-level management. However, it should be noted that while stores were codifying the expectations that they held for managers, that did not always mean that those protocols were carried out as written. Managers often made as few adjustments as possible to their own practices, while trying to implement massive changes on the sales staff through store education programs and changing rules. ${ }^{226}$ In some cases, managers also had the responsibility of creating files on each of their saleswomen, detailing their strengths and weakness. These reports were first used by Macy's in 1915 and by 1920 they were being analyzed to identify employees in need of remediation or reassignment. ${ }^{227}$

While floor managers and other levels of management may have enjoyed the influence that they had over staff members, these positions were accompanied by a number of frustrations. The sheer number of employees that store managers had to

\footnotetext{
224 “Floorman's Manual," 20.

225 Ibid, 19.

${ }^{226}$ Benson, Counter Cultures, 140-141.

${ }^{227}$ Malino, "Faces Across the Counter," 88-89.
} 
contend with could be daunting. In 1904, Marshall Field's had a workforce that fluctuated between eight and ten thousand people serving up to 250,000 customers per day. Balancing the needs of both the numerous department store employees and their customers was undoubtedly a difficult task for managers. ${ }^{228}$ This could prove even more difficult with the large seasonal variations in the number of customers. Stores were swamped during the winter months and nearly empty during the heat of the summer. Business was busy on Saturdays and Mondays, but slow on Fridays. Managers had to find a way to maintain staffing levels that provided quality of service at all times, but also protected the store's bottom line. ${ }^{229}$ It was also difficult to gauge the effectiveness of store policies that influenced sales because of the measurement of success was the volume of entries in a clerk's salesbook. Managers found it difficult to determine what portion of these sales were due to the skill of the sales staff versus the appeal of the product. ${ }^{230}$ Furthermore, a high sales volume did not necessarily equate with a quality salesperson if those items were later returned or the customer was displeased and took future business elsewhere. ${ }^{231}$ Store managers had to be careful with how they instructed the sales staff in store policies and provided feedback on their performance. As a public space, the working conditions of saleswomen were open to criticism by customers, many of whom were the middle-class women who championed work reforms for female department store employees. ${ }^{232}$ Pleasing and maintaining the loyalty of those customers was always an important focus for department stores.

\footnotetext{
${ }^{228}$ Benson, Counter Cultures, 34.

${ }^{229}$ Ibid, 37.

${ }^{230}$ Ibid, 35-36.

${ }^{231}$ Ibid, 127.

${ }^{232}$ Ibid, 128.
} 


\section{Customer Interactions}

The desire to create the ideal shopping experience made interaction between salesclerks and customers a top priority for store managers. Their own roots in middleclass culture made them uniquely aware of the expectations that middle-class customers had of saleswomen. Attempts to improve employee-customer interactions began early. Stores like Marshall Field's first began to regulate these interactions in the 1890s, when employees were warned to keep "respectable and moral associations" outside of work and to use the formal reference of "Madame" when speaking to an unknown lady. ${ }^{233}$ Making shoppers as comfortable as possible in the store by mimicking their values made it much more likely that they would become repeat customers. By 1911, Marshall Field's was including even more of these middle-class expectations in the "Book of Rules," the booklet all employees received outlining store expectations. Employees were supposed to use proper prefixes for employees and customers alike, were banned from linking arms with each other around the store, and were barred from using most colloquialisms. ${ }^{234}$ Store dress codes were also outlined in the "Book of Rules."

Dress codes and their enforcement by department stores is evidence of the paternalistic relationship between the department store and its female employees during the time period. According to Susan Porter Benson, rule books were created because of the large size of department stores, the need for fairness, and a desire to encourage appropriate behaviors. ${ }^{235}$ Similarly, dress codes helped to create uniformity, minimize

\footnotetext{
233 "Book of Rules," 1891, Box 03024, "Marshall Field and Company Records," Chicago Historical Society, Chicago, 1.

234 "Book of Rules," 1911, Box 03024, "Marshall Field and Company Records," Chicago Historical Society, Chicago, 14-15 \&18

${ }^{235}$ Benson, Counter Cultures 139.
} 
poor taste by the clerk, and create a separation between the salesperson and customer. ${ }^{236}$ According to Benson, many saleswomen saw these restrictions as insulting because they questioned or restricted their fashion choices. If clerks were emulating their middle-class customers, they reasoned that they should be deemed capable of making appropriate choices in dress by store managers. Employees also accused the store of sending mixed messages with their dress codes. On the one hand, employees were being asked to embrace fashion and be knowledgeable about stylish dress, but on the other hand, saleswomen were relegated to wearing dull and inconspicuous clothing, usually a white waist and black skirt. ${ }^{237}$ A 1916 business advice column in the Chicago Tribune took the stance that while the restrictions may have been "an arbitrary limitation" and "resented by the girls as unfair" that management was using it as a "practical solution" to "add to the attractiveness of the store." 238 Dress codes could also restrict the attire of women outside the store if the clerk could not afford to purchase two wardrobes and was forced to wear her work-wear socially. In a small number of cases, dress codes even led to stealing because women who could not afford a second set of clothes stole items to create a leisure wardrobe. ${ }^{239}$

In addition to emphasizing middle-class social behaviors through store rules, some department stores offered formalized education in these norms. As more and more working-class women were hired by the store, management discovered that the oral and written English skills of their sales staff did not match their expectations. Through a specific division set up to improve the skills of their working-class staff, the Educational

\footnotetext{
${ }^{236}$ Ibid, 140.

${ }^{237}$ Ibid, 236.

${ }^{238}$ King, Mary, "For and By Business Girls," Chicago Daily Tribune, September 17, 1916, D6.

${ }^{239}$ Benson, Counter Cultures, 238.
} 
and Efficiency bureau, Marshall Field's began offering classes in English. These courses focused on improving spoken English and avoiding its errors of speech. ${ }^{240}$ These classes were most likely created to mask working-class speech patterns. Particularly in industrialized states, like Illinois, clerks were less likely than women in other professions to be foreign-born; a vast majority would have been native-born. ${ }^{241}$ These factors minimize the likelihood that English classes were created to help non-native speakers. The store also opened an on-site library with over 2,800 titles available for employees to check-out. $^{242}$ Employees were allowed to create drafts of correspondence with customers, but had to have them proofread and typed by the secretarial staff because the company feared that they would commit too many composition errors. ${ }^{243}$

Although these programs benefitted store employees by improving their education, stores were primarily motivated, not by altruism, but business. Management realized that the image of their store would be damaged in the eyes of the middle-class if their employees seemed un-educated and ill-suited to serve them. They believed that customers were deeply offended by employees who did not use English properly, which lowered the dignity of the store and might cost them customers. ${ }^{244}$

While working-class department store clerks were frequently judged by their middle-class customers, the reverse was also true. The volume of traffic and sales in department stores meant that many saleswomen felt that they had a solid grasp on how the social class of a customer related to their purchases. According to a 1904 Chicago

\footnotetext{
240 "Educational and Efficiency Bureau Report," 1919, Box 18002, "Marshall Field and Company Records," Chicago Historical Society, Chicago, 1.

${ }^{241}$ Benson, Counter Cultures, 209.

242 "Educational and Efficiency Bureau Report," 2.

${ }^{243}$ Ibid, 4.

244 "Developing the Workers," 1913, Box 18051, "Marshall Field and Company Records," Chicago Historical Society, Chicago, 2-3.
} 
Tribune article, salesclerks believed that they could predict the social class of a customer and their sales by the hour of the day. According to the saleswomen, the upper-classes did their shopping in the morning so that they could return home in time for lunch. The clerks interviewed said that they preferred these customers, not only because they helped increase their sales commissions, but also because they were able to serve them at the beginning of the day when they were "fresh." Wealthy customers also seemed to prefer Tuesdays and Wednesdays when they could avoid the bargain hunting crowds earlier and later in the week.

The clerks had a much lower opinion of the "matinee crowd," the group that arrived following afternoon shows. Clerks admitted that they came from all social classes, but tended to be tackily dressed. But the most disliked were those who arrived just before closing. The article is scathing toward these customers calling them "selfish" and "grossly inconsiderate." ${ }^{245}$ What it fails to consider is why these customers waited until early evening to shop. Very likely, they were working-class people who were stopping by the store after their shift. This shows that clerks were aspirational, seeing themselves as a somehow superior to these working-class patrons, and that they had adapted to some degree the values of store management. Any compassion that clerks might have felt for people in a similar economic situation to themselves quickly dried up at closing time. The clerks were also critical of middle-class Monday shoppers who came in looking for bargains from the weekend advertisements. They were criticized for buying too much and what was unfashionable because it was out of season or of poor taste. The "poorer relation" of the Monday shopper was the Friday bargain basement shopper. These working-class women were accused not only of looking for bargains, but

245 “Classify Shoppers By the Day and Hour," Chicago Daily Tribune, June 5, 1904, 23. 
being demanding, rude, and even abusive. ${ }^{246}$ Contrary to the assessment of the clerks, the demanding and pushy nature of this shopper may have been a misinterpretation of her desperation to buy the goods that she needed or desired on a limited budget. This is evidence that saleswomen internalized social class stereotypes and readily applied them to the business of selling. Tensions between social classes could exist as easily between working-class clerks and impoverished bargain basement shoppers as it could between the clerks and urban socialites.

\section{Middle-Class Views of Saleswomen}

Regardless of the realities, department stores were eager to prove to the buying public that their saleswomen exemplified middle-class values and were not, contrary to popular belief, poorly educated and ill-mannered members of the working-class. According to a 1907 Chicago Tribune article, the average female department store clerk possessed a level of education on par with that of a lower-grade elementary school teacher. Yet, the manager of a large department store who was interviewed for the article insisted that his store most often hired women who had graduated from high school and required that all employees had completed schooling through eighth grade. However, there are several points to consider when assessing the situation of female clerks. First, the article is only advising the public on the qualifications of the "average" clerk. Obviously, there were many clerks who were not as well-educated. Second, store managers were predominantly speaking about year-round salespeople. The numbers of clerks employed by department stores increased dramatically during the holiday months. ${ }^{247}$ While the department store might have employed well-educated, year-round

\footnotetext{
${ }^{246}$ Ibid, 23.

${ }^{247}$ Raymond, "Saleswomen Are Well Educated," 1.
} 
employees, the women who filled out the staff during the fall and winter months may have lacked a lengthy formal education.

In addition to saleswomen's education, the article discusses other issues that would have been of interest to middle-class readers. It points out that most saleswomen were single and intended to eventually marry, were earning low wages because they were not fully independent from family, and that they made up a smaller proportion of working women than the public would be led to believe. ${ }^{248}$ On the whole, the managers in the article seem to be apologizing for and rationalizing the presence of female clerks. It suggests that the paper's readership was still uncomfortable with such high-profile working women and that if these women were to be employed in stores, they should represent middle-class values of high educational attainment and a desire to enter marriage and family life as soon as possible. This might have been the plan for some saleswomen, but for those whom it was not, it must have been disheartening to discover that their employer was promoting the same norms that frustrated them in their personal lives.

Despite the fact that department store managers were trying to make it appear as though their workforce was marginally middle-class, they were largely unsuccessful in convincing middle-class parents that being a saleswoman was an appropriate career choice for their daughters. In 1907, the same year that the Chicago Tribune was telling its readers that saleswomen were well-educated scholastically and socially, the newspaper wrote a story explaining how its upper and middle-class readership could prevent their daughters from becoming department store clerks by taking them to a melodrama, "Lottie the Poor Saleslady; or Death Before Dishonor." The play follows its ${ }^{248}$ Ibid, 1. 
naïve title character as she moves to New York City to work as a saleswoman in a fashionable store. She excels at her job, but has caught the eye of the store's owner who offers her an indecent proposal: become his mistress and he will set her up in a store of her own. When Lottie refuses, she is fired, but family connections keep her villain in pursuit while she toils as a saleslady. As in any melodrama, Lottie is saved from near death at the end of the show, while the villain is foiled and she is united with her true love. $^{249}$

While the play may have followed a typical formula, it also reveals some of society's underlying concerns about saleswomen. Lottie is portrayed as a working-class woman who is targeted by a morally corrupt, upper-class man. This speaks to public concerns about young women's ability to maintain their morality in an environment of considerable gender and class conflict. That Lottie's boss was both male and wealthy made it difficult for her to resist his advances. However, in keeping with Victorian ideals, Lottie is morally incorruptible and refuses him. When the heroine is fired, the plotline recognizes that this outcome would have been realistic for many in Lottie's position. The story might have generated sympathy for salesclerks, but it was certainly not advocating it as a good profession for young women. On the contrary, the melodrama expressed Victorian society's concerns that a working woman's virtue would be endangered as a salesclerk. In this light, the Tribune article advises its readers that upper-class parents bring their daughters to view it as a moral warning. The paper suggests that any young woman, including the working-class audience, who had romantic

\footnotetext{
249 "How to Keep Your Daughter from Becoming a Saleslady," Chicago Daily Tribune, November 10,
} 1907, B1. 
notions of department store work or wanted to join the working world as a sociological experiment would be deterred by the plight of Lottie. ${ }^{250}$

Work in the department store might have been common, but from the point of view of middle and upper-class Chicagoans, it should only have been taken up out of economic necessity, that is, by working-class girls. Some middle-class women did find an appeal in department store work which they hoped would allow them to incorporate their interests in fashion and style into a career. However, this aspect of salesmanship was often over-glamorized, a point that middle-class women well-noted. Their extensive education, while appreciated, was not necessary for working in department stores and gave them options that many working-class women did not have. Alternatively, middleclass women could often find work as office clerks or teachers, jobs that paid more, had better hours, and carried greater prestige than department store work. The number of young, middle-class women looking to work outside the home did not yet necessitate their employment in traditionally working-class sales positions. ${ }^{251}$ This viewpoint would change in the late 1920s and 1930s as more middle-class women sought employment outside the home before marriage.

With many middle-class women not yet opting to seek employment in department stores, the large influx of working class female department store clerks left the middleclass unsure of how to receive saleswomen. As a result, company policies and the experiences of clerks and customers varied widely from store to store. Women in department store work found themselves engaged in gender conflicts within a patriarchal society and on a smaller scale with their male bosses. Similarly, they had to negotiate

${ }^{250}$ Ibid, B1.

${ }^{251}$ Fine, Souls of the Skyscraper, 44. 
class conflicts within the open, yet divided social structure of a department store. Over time, the Victorian values of middle-class America were institutionalized into the store system resulting in tight control over employee behavior. Employees accepted some of these regulations, often overseen by middle-class managers, and tried to defy others. 


\section{CHAPTER IV \\ MIDDLE-CLASS REFORMERS AND THEIR IMPACT}

As middle-class reformers set out to improve the city that they called home, they turned their attention to those who they perceived as particularly vulnerable. They targeted young saleswomen hoping to improve their working conditions. Yet, as they did so, they imposed upon them their own middle-class expectations. The values of middleclass reformers often mirrored those of middle-class managers with an end result of paternalistic policies that improved the conditions that clerks labored under, but denied them independence. However, by the 1920s, movement towards the professionalization of selling and demands for greater autonomy from a generation of "New Women" led to significant improvements in the working lives of saleswomen.

\section{Origins of the Reform Movement}

"When I took a walk, I liked to go to the poorer parts of town and see what was going on..." writes Louis DeKoven Bowen in her autobiography. "I used to walk...in a neighborhood known as 'Little Hell' ... [The residents] had been ruthlessly exploited...they found themselves with very little money...[and] rented unsanitary tenements...taking what work they could get., ${ }^{, 252}$ The neighborhood described by Bowen was probably not dissimilar to the neighborhoods where most working-class saleswomen lived and it was the terrible conditions that these laboring women faced at home and at

${ }^{252}$ Louise DeKoven Bowen, Growing Up with a City (Urbana: University of Illinois Press, 2002; 1926), 66-67. 
work that drew Bowen into the reform movement. Bowen's experience was not unlike that of many progressive reformers who saw the darker side of the city and tried to change it. The chaotic and frenzied growth of cities had brought with it poverty, blight, corruption, and a lack of basic services. Urbanites were frustrated and angry at what they perceived to be the failure of government and society-at-large to remedy these problems and were motivated to engage in reform. ${ }^{253}$ "Men in confusion clutched to what they knew," Robert Weibe contends. To the middle class, the social order was in disarray, and bureaucratic reform was the way to control the chaos. ${ }^{254}$

A methodical, almost scientific, approach underpinned many Progressive activities because reformers believed that it would create an orderly and fair society. Influenced by advances in science and the rise of the social sciences, reformers often advocated "perfect" or proper ways of delivering services or operating within society. ${ }^{255}$ Wiebe contends that reformers often advanced their cause by appealing to "experts" in a given field. ${ }^{256}$ Middle-class women viewed themselves as the authority on issues relating to morality and the home and by extension, guardians of the welfare of the nation.

However, in order to best utilize that expertise, middle-class women needed additional training. Reform work relied on investigations, statistical reports, and political lobbying to advance its agenda. Social services were thus elevated to the professional arena and

\footnotetext{
${ }^{253}$ Wiebe, Search for Order, 167.

${ }^{254}$ Ibid, 302.

${ }^{255}$ Ibid, 170.

${ }^{256}$ Ibid, 174. See also: Robyn Muncy, Creating a Female Dominion in American Reform, 1890-1935 (New York: Oxford University Press, 1991), xii-xiii. Muncy describes how the reform movement professionalized as a number of organizations formed a "female dominion." She argues that within this dominion, "activity, confidence, and self-assertion" were demanded, while women held considerable authority operating within a male-dominated policy sphere.
} 
universities or other institutions of higher education began offering courses designed to give female reformers the skills necessary to carry out reform agenda ${ }^{257}$

Many of these women were examples of the "New Woman," the educated, professional, and independent woman that first appeared in the late-1800s, challenging prevailing attitudes about femininity and creating public debate about the "naturalness" of her behavior. Smith-Rosenberg explains how these women were eventually deemed "unnatural" and symptomatic of a society gone wrong. ${ }^{258}$ The reform community was awkwardly divided in their views of the "New Woman." For some, she represented a woman who rejected her "feminine nature" by eschewing traditional family life, but for others, she was indispensable as many of the reform movement's greatest leaders were “New Women” themselves. Jane Addams, Chicago's most legendary reformer, and her contemporaries fiercely defended their new public roles and argued that their work as "mothers" to the community was evidence of their "“womanly' natures." 259 Despite some criticisms, this early generation of "New Women" were more widely accepted by society than later generations who adopted a more androgynous identity and were often scorned. ${ }^{260}$

The reform movement eventually led by the "new women" of Chicago traces its origins to the aftermath of the 1871 Great Fire. Women in the city first organized as relief workers because they believed that male city leaders were not adequately concerned about the needs of impoverished fire victims. While men in the business community tried to organize reconstruction and relief in a way that would benefit local

\footnotetext{
${ }^{257}$ Kessler-Harris, Out to Work, 115.

${ }^{258}$ Smith-Rosenberg, Disorderly Conduct, 245.

${ }^{259}$ Ibid, 263.

${ }^{260}$ Ibid, 296.
} 
entrepreneurs, female relief workers argued that no supplies or aid should be rejected regardless of whether it was offered from inside or outside the community. For these women, immediate relief and the restoration of families was of the greatest importance, a theme that would continue throughout the history of the city's reform movement. ${ }^{261}$ Prior to the Great Fire, women who assisted those in need did so primarily through private charities, but after, they appealed for more institutional changes. ${ }^{262}$ In order to accomplish this, they formed groups that would focus on reform as a means to create lasting change that temporary charity could not.

These groups steadily grew and Chicago gained notoriety for the richness of its reform movement. Although smaller groups preceded it, the Illinois Women's Alliance, formed in 1888 , was a forerunner in the city's reform movement and influential in the reform organizations that followed it. What made the IWA notable was that its membership spread across social classes. While a majority of its members were middleclass, Flanagan describes the group as decidedly "pro-labor," "pro-women," and "prochildren." They rejected the idea that government should stay out of the affairs of private business and insisted that politicians should work for the protection of working women and their families. ${ }^{263}$ Leaders called women to the group saying they should "amend the conditions..[of] less fortunate sisters." 264 These "sisters" were understood to be white, as racism was widespread within the middle-class reform movement. Indeed, it was progressives who saw segregation as the solution to racial tension, making it unlikely that

\footnotetext{
${ }^{261}$ Flanagan, Seeing With Their Hearts, 29.

${ }^{262}$ Ibid, 31.

${ }^{263}$ Ibid, 37.

${ }^{264}$ Ibid, 39.
} 
African Americans would want to form permanent association with white progressives. ${ }^{265}$ With its predominantly white, but economically varied membership, the IWA tried to accomplish its goal of increased regulation of business by raising women's public profile in the city. Members made appearances at city hall, in courtrooms, and before boards of education to try and promote their causes. By doing so, they removed some of the stigma associated with women appearing in such powerful public arenas. ${ }^{266}$ Years later, unique circumstances brought groups together who would work in the tradition of the IWA to improve living and working conditions by forming association between otherwise disparate individuals.

Subsequent events in the city further strengthened the reform movement, most notably the 1893 Columbian Exposition and the 1894 Pullman Strike. The former helped to increase the public influence of Chicago's female population, since women played an important role in organizing fair activities. In the course of this work, they were able to advocate for the rights of Chicago's diverse female population by ensuring the Exposition's operation on Sundays, enabling access by working women, and by trying to include African-American women on the board of managers. ${ }^{267}$ During the Pullman Strike, many middle-class women sympathized with the wives of striking workers and tried to provide financial support for their families. More importantly, the strike convinced many reformers that the problems of one segment of the city's population impacted the well-being of all of its citizens. ${ }^{268}$ Social classes developed solidarity within their own groups, but the nature of urban life made them interdependent with other

\footnotetext{
${ }^{265}$ McGerr, Fierce Discontent, 202.

${ }^{266}$ Flanagan, Seeing With Their Hearts, 44.

${ }^{267}$ Ibid, 57.

${ }^{268}$ Ibid, 58.
} 
classes. Recognizing this, middle class reformers also emphasized association with the working class, establishing both cooperation and control simultaneously. ${ }^{269}$ In their capacity as “True Women," as Smith-Rosenberg explains, middle-class women sought to cooperate with working-class women to improve their working conditions and educational opportunities.

The considerable effort that the Chicago reform movement made to create alliances with organizations from differing class, ethnic, religious, neighborhood, and, on occasion, racial groups set it apart from other reform movements around the nation. This would later be important in the context of their work with female salesclerks. Reformers were on a mission to serve the "common welfare" of the city, and these alliances helped them to include all segments of society in the process. ${ }^{270}$ That is not to say that middleclass women and their wealthy patrons did not dominate the leadership of these organizations, but that Chicago associations were less likely to exclude perceived outsiders. The demographic make-up of the city likely assisted in the adoption of this policy. Unlike East-Coast cities that were bound by established notions of elitism or the new cities of the West, dependent on the newly rich, Chicago's social scene was more fluid. Chicago's rapid economic growth drew migrants from all over of the nation who were less concerned with rigid class structures. ${ }^{271}$ This was one of the original intents of Hull House, the settlement association, which dominated Chicago's social progressive movement and spawned many of its reform organizations. These organizations were the link between the urban poor and the privileged classes who operated the city's charity

\footnotetext{
${ }^{269}$ McGerr, Fierce Discontent, 67.

${ }^{270}$ Flanagan, Seeing With Their Hearts, 147.

${ }^{271}$ Ibid, 149-150.
} 
organizations. Through reform organizations, such as the Hull House Association, these groups were brought together to push for lasting reforms over temporary solutions. ${ }^{272}$

Louise DeKoven Bowen recounts this type of association in her autobiography. Bowen, a woman of considerable wealth, was invited by Jane Addams to join the Hull House Women's Club, an organization made up primarily of the poor, immigrant women from the surrounding neighborhood. ${ }^{273}$ While initially uncertain of her role, Bowen was fortified by the intelligence and determination of the other women in the group. She would later credit this experience as integral in helping her establish herself as a capable public speaker and cementing her relationship to Hull House and its associated organizations. ${ }^{274}$ Bowen would go on to become the treasurer of the Hull House and president of the influential Juvenile Protective Association. Reform work and activism became her life's work and most of her reform goals centered around children, women, and families. She also used much of her considerable family wealth to bankroll a large number of reform organizations and used her social connections to support their fundraising efforts. ${ }^{275}$ Scores of Chicagoans were inspired by experiences like Bowen's to form groups that not only discussed the problems facing the city, but took action to remedy them. Eventually, some of these groups targeted the city's female department store clerks in a number of their campaigns, many of which centered on compensation and working conditions.

By the 1880s when middle-class reformers began to push for equal pay for equal work, working-class women balked. The working-class viewed higher wages for men as

\footnotetext{
272 Flanagan, America Reformed, 36.

${ }^{273}$ Bowen, Growing Up, 82.

274 Ibid, 83.

${ }^{275}$ Rima Lunin Schultz and Adele Hast, ed. Women Building Chicago 1790-1990: A Biographical Dictionary (Bloomington: Indiana University Press, 2001), 101.
} 
the key to economic survival, and a rift subsequently developed between the two groups of women. ${ }^{276}$ Reformers also turned their interest to the growing number of women adrift, young women who lived apart from family and supported themselves. By 1900, they made up twenty percent of all wage earning women. ${ }^{277}$ These working-class women were unique from their peers because their need for a self-supporting income might have resulted in close cooperation with middle-class reformers who advocated for higher wages. Yet often these young women resented the intrusion of middle-class reformers into their lives. For their part, middle-class women feared that these economically vulnerable women, such as those working for low wages as saleswomen, would be at risk for sliding into prostitution. ${ }^{278}$

\section{Motivations of Reformers}

Middle-class reformers were particularly worried about the negative effects that low wages might have on independent young women. As more women entered the workforce, ideas about a woman's role in society and moral behavior were pushed from the privacy of home into public spaces. They formed organizations to advance these goals and worried about what they saw as a connection between low pay and immoral behavior. Reformers often targeted working-class women because they feared that their ill treatment was a threat to society at large. They reasoned that if working women were lifted out of poverty and protected from influences that might threaten their "womanly

\footnotetext{
${ }^{276}$ Smith-Rosenberg, Disorderly Conduct, 174-175.

${ }^{277}$ Meyerowitz, Women Adrift, xvii.

${ }^{278}$ This concern was connected to the idea of "white slavery" in which young, white women were supposedly trafficked into prostitution. Middle-class reformers widely accepted this belief as valid. See Meyerowitz, Women Adrift, 62.
} 
virtues" that they would provide better care for their families (or future families).

Preservation or a return to traditional family roles was given a high priority. ${ }^{279}$

Considerable historiographical debate exists about the nature of the relationship between middle-class reformers and the working-class women that they targeted. In Seeing With Their Hearts, her book on the Chicago reform movement, Maureen Flanagan agrees that solidarity with other women regardless of class, sometimes even ethnicity and race, was a major motivation for female reformers. She argues that this mindset allowed women to recognize their social differences, while at the same time work together to reach common goals. ${ }^{280}$ Conversely, Kessler-Harris contends that progressive women saw their intervention on behalf of working women as a type of "maternal" duty, ${ }^{281}$ suggesting less cross-class unity than Flanagan assumes. ${ }^{282}$ In A Fierce Discontent, Michael McGerr seems to reconcile these two viewpoints. He argues that middle-class reformers wanted to witness a "moral revolution" in both the upper and lower-classes. Of course they envisioned that revolution would embrace the values of the middle-class, but they also sought to create unity across class lines. By embracing a singular moral ethic, Americans would be able to rise above their class differences. ${ }^{283}$

Both extremes of this debate can be validated to certain degree and often within a single organization. Jane Addams clearly exhibited the viewpoint argued by Flanagan. In a notable illustration, she chastised Louis DeKoven Bowen for feeling irritation at the lack of gratitude on the part of a poor, immigrant women whom she had assisted.

\footnotetext{
${ }^{279}$ Kessler-Harris, Out to Work, 90.

${ }^{280}$ Flanagan, Seeing With Their Hearts, 6.

${ }^{281}$ Kessler-Harris' viewpoint bears resemblance to that of Robert Wiebe who called middle-class reformers "impatient, sometimes arrogant" and criticized their assumption that "all good citizens shared their goals." Robert H. Weibe, The Search for Order, 1877-1920 (New York: Hill and Wang, 1967), 212.

${ }^{282}$ Kessler-Harris, Out to Work, 115.

${ }^{283}$ McGerr, Fierce Discontent, 135.
} 
Responding to Bowen's complaints rhetorically, she asked if receiving gratitude was her motivation for service. ${ }^{284}$ The implied answer of course was "no." Indeed, Bowen appears to confirm Kessler-Harris' interpretation, since she did seem to intentionally elevate herself over the working class women that she worked with in the reform movement. Although, she was a member of many organizations that brought working, middle, and upper class women together, she nearly always served within their leadership. McGerr's argument seems to be able to explain the mixed messages conveyed by women like Bowen. While women like Bowen desired class unity, they sought that unity around the middle-class ideals that they promoted.

\section{Efforts of Reformers}

Chicago reformers, like Louise DeKoven Bowen began to take interest in the troubles of female department store workers during the second decade of the twentieth century. This interest was likely primarily connected to the concern that they had about the moral behavior of clerks and, to a lesser extent, concerns about working conditions. Jane Addams summed up the commonly held morality concerns well in her 1912 book, $A$ New Conscience and An Ancient Evil. "It is in the department store more than anywhere else that every possible weakness in a girl is detected and traded upon." She wrote "wherever many girls are gathered more or less unprotected and embroiled in the struggle for a livelihood, near by will be hovering...[the] evil-minded."285 Her message was clear; in the minds of middle-class reformers, saleswomen were at high-risk for being lured into liaisons with male customers and prostitution.

\footnotetext{
${ }^{284}$ Bowen, Growing Up, 87-88.

285 Jane Addams, A New Conscience and an Ancient Evil (New York: The Macmillan Company, 1912$), 64$.
} 
In 1911, the influential Juvenile Protective Association, led by Bowen, took up the cause, compiling a report on working conditions in department stores based on interviews with 200 clerks from thirty stores around the city of Chicago. The study found that a large proportion of the women -173 out of 200 - were living at home with relatives. This may have made them less vulnerable than women who had to provide for the necessities of life themselves, but it did not mean that they had control over their own finances. Most women were adding their earnings to the family coffers and very few could save wages exclusively for their own use. For women who did live away from family and without outside support, providing for themselves was extremely difficult on a clerk's salary. The study revealed that female department store employees earned between $\$ 2.50$ and $\$ 11.00$ per week, with the majority of women earning a wage near the middle. ${ }^{286}$ Reformers calculated that it was impossible for a woman to live independently in Chicago on less than $\$ 8.00$ per week. Bowen lamented that for a saleswoman living on her own, after the costs of room, board, clothing, and transportation, nothing was left over for amusement or savings. Unfortunately, there were many women who lived on that amount or less. She claimed that they survived by living in substandard rooms and eating food of little nutritional value. ${ }^{287}$ When Bowen testified before a 1913 Illinois State Senate Committee on wages, she claimed that eight dollars a week would be sufficient for most women to cover a decent standard of living, yet the testimony of department store managers reveals that many women were barely making this much. For

\footnotetext{
${ }^{286}$ Bowen, Department Store Girl, 2.

${ }^{287}$ Ibid, 3.
} 
example, a manager from Siegel Cooper testified that an average wage at the store was $\$ 8.56$ per week and over fifty women earned less than five dollars. ${ }^{288}$

Members of the JPA were not only concerned with the physical well-being of the female department store worker, but more controversially, they believed that these conditions made women susceptible to immoral behavior. The investigators believed that because clerks were surrounded by commercial temptations at work that they would be desperate for entertainment outside of work. ${ }^{289}$ Since they were unlikely to have the money to pay for these luxuries themselves, they would have to be treated to them by men. As discussed earlier, the middle-class reformers who made up the JPA saw low wages as a slippery slope to prostitution, but also the common practice of treating, in which young women exchanged sexual activity for leisure expenses. ${ }^{290}$ Elizabeth Clement argues that treating highlighted a fundamental difference between the working and middle-classes. While middle-class women saw treating as quasi-prostitution, working-class women saw the practice as distinct from prostitution. ${ }^{291}$ Working women were also more likely to debate the morality of treating among themselves, rather than with middle-class reformers, a conclusion that Clement draws due to the large number of familial arguments in records made by social workers. This would have made it more difficult for reformers to impose the moral behaviors that they championed if young women merely gave them lip service. ${ }^{292}$

\footnotetext{
${ }^{288}$ Report of the Senate Vice Committee, 1916, 455, 240.

${ }^{289}$ Bowen, Department Store Girl, 5.

${ }^{290}$ Elizabeth Alice Clement, Love for Sale: Courting, Treating, and Prostitution in New York City, 1900 1945 (Chapel Hill: University of North Carolina Press, 2006), 1.

${ }^{291}$ Ibid, 59. See also: Meyerowitz, Women Adrift, 101-104. Meyerowitz holds similar views to Clement about the acceptance of treating in working-class society and contends that young women were very deliberate in their decision to exchange sexual favors for access to amusements.

${ }^{292}$ Ibid, 7.
} 
JPA investigators were also concerned with the vulnerable position that saleswomen held in the store. Male customers held considerable power over clerks. "It frequently happens," the pamphlet reads, "that if a girl refuses to have any conversation with the man outside of business communications, he reports her as impertinent to the manager." The rejected man could easily issue a false complaint against a saleswoman which could result in her firing. ${ }^{293}$ There was also concern that women might be harassed by their male superiors at work. "The girl is at the mercy of 'the man higher up' in her department," Bowen claimed. If a male superior showed interest in a female employee, it would be very difficult for her not become involved with him without fear for her job. The JPA cites the example of a young woman whom they had recently assisted in finding a new position. She was working as a department store clerk when the head of her department showed an interest in her. Not wanting to begin a relationship with him, she was fearful for her job, quit, and turned to the JPA for help. ${ }^{294}$ Middle-class women believed that females were frequently the victims of dishonorable men, often their employers, and that working women would gladly seek help by the middle-class women. ${ }^{295}$ While this may have been occasionally true (as in the case of the women just described) as Peiss argues, working women were often hostile to the maternalistic actions of reformers.

The report did not limit its focus only to the dangers that faced women from a lack of pay or their contact with male customers and managers, but also explored many of the other difficulties of clerking: the physical strain of the job, the long workdays, the stressful holiday periods, and the lengthy commutes. The JPA expressed concern over

\footnotetext{
${ }^{293}$ Bowen, Department Store Girl, 6-7.

294 Ibid, 6.

295 Peiss, Cheap Amusements, 166.
} 
the conditions in "outlying stores," those beyond the Loop, which often had harsher working conditions and longer hours. ${ }^{296}$ The report also made the association's case for a half-day off on Saturdays, which it had long advocated as a time for recreation and time with family. ${ }^{297}$ The depressing story of one clerk who "wished she was dead," due to the exhausting conditions of her work, and several accounts of young women driven into prostitution wrap up the report with an emotional appeal for a "living wage" for department store clerks. ${ }^{298}$ The moral concerns held by Bowen were also shared by other reformers, including Jane Addams. In A New Conscience and an Ancient Evil, Addams writes of saleswomen, "inexperienced girls are either deceived or yield to temptation in spite of the efforts made to protect them by the management and by the older women in the establishment.",299

The approach of the report is interesting because while it advocates heavily for the safety and physical well-being of saleswomen, it does not call for their increased autonomy. Greater ability to rise within the department store and influence management might have solved many of the problems that middle-class reformers were concerned about. More important positions would have meant higher pay and a greater equality with men, making it less likely that women would have been driven into "immoral" behaviors or harassed by male-coworkers. They also would have had better opportunities to improve their working conditions. By ignoring these opportunities, the JPA reveals their middle-class bias. Instead of trying to empower working class women, they were trying to assist them in conforming to middle-class expectations.

\footnotetext{
${ }^{296}$ Bowen, Department Store Girl, 7.

${ }^{297}$ Ibid, 11.

298 Ibid, 12- 13.

${ }^{299}$ Addams, New Conscience, 64.
} 
What middle-class reformers expected saleswomen to focus on was becoming good wives and mothers, and to view their presence in the workforce as temporary. ${ }^{300}$ Advancement in the workplace did not align with this view, therefore it was not a priority of the reform movement. In fact, women's clubs sponsored by reform organizations promoted the idea that women should not seek “men's work or place.” They believed that women should earn a wage that enabled self-support, but beyond that they should be content with their position. ${ }^{301}$ Class tensions became common in these clubs when some working women felt that middle-class organizers were disconnected from the workingclass membership. ${ }^{302}$ However, ideas about the public lives of women were not always divided along class lines. Sarah Deutsch points out in her book on female Bostonians that often immigrant parents were in agreement with middle-class reformers that working-class girls needed to be controlled. These parents feared the commercialized leisure activities that engaged their daughters and felt more comfortable with the restrained leisure activities organized by women's clubs and employers. ${ }^{303}$ On more general issues that benefitted all women, the reform movement could claim a large amount of success. The work of progressive reformers did help to legitimize female participation in public and political life. It also created new job opportunities for middleclass women in social work and investigation that would have been previously unavailable to them. ${ }^{304}$

One of the main goals of these professionalized reformers was to create associations between groups to help working women. Smith-Rosenberg suggests that this

\footnotetext{
${ }^{300}$ Peiss, Cheap Amusements, 163.

${ }^{301}$ Ibid, 170.

${ }^{302}$ Ibid, 172.

${ }^{303}$ Deutsch, Women and the City, 81; Peiss, Cheap Amusements, 72.

${ }^{304}$ Kessler-Harris, Out to Work, 115.
} 
solidarity had its roots in "traditional patterns of female intimacy" in which women developed deep love and enduring friendships with one another. ${ }^{305}$ Yet, despite the genuine feelings of affection that might have drawn middle-class women to workingclass women, they still tried to operate their reform agendas under terms dictated by the middle-class. Lara Vapnek describes how some reform organizations attempted to generate cross-alliance through top-down leadership. In the retail world, the New York Consumers' League was a good example. The league worked with saleswomen to highlight their poor working conditions and convince middle and upper-class women to patronize only those stores that treated their female workers fairly. However, there were problems with this alliance. As with trade unions, the leadership was generally not controlled by working women and in the case of the NYCL, working women were even barred from membership. Vapnek also points out that some working women opposed the public relations campaign of the reform group and resented being portrayed as helpless victims in the media. ${ }^{306}$

On the other hand, the League was effective in making improvements in the wage and working conditions of female department store employees. The League was able to force stores to provide gender equal pay, a minimum wage, paid overtime, set hours, and sanitary employee facilities. Failure to adopt these policies meant that a store was excluded from the organization's "white list" and was therefore boycotted by conscientious consumers. However, beyond the threat of exclusion from the "white list," the League had little recourse against department stores and therefore had less impact

\footnotetext{
${ }^{305}$ Smith-Rosenberg, Disorderly Conduct, 264.

${ }^{306}$ Vapnek, Breadwinners, 87.
} 
than a saleswomen's trade union might have. ${ }^{307}$ Given the lack of unionization in the retail sector, the upper-class women who led the NYCL believed that they and the organization's middle class supporters were fulfilling an important role in advocating for the rights of saleswomen. For their part, working women had mixed feelings about the organization. They appreciated its success in improving working conditions, but many saleswomen were upset by the "condescending" attitude they with which they were treated by the group's organizers, who often labeled clerks as " "timid'... and lacking 'the wisdom, strength of character, or experience...to act on their own behalf.",308 Yet, the successes of the NYCL do provide a good example of what types of reform activists were able to secure for saleswomen.

\section{Role of the Labor Movement}

During the period from 1880-1930, the middle-class progressive reform movement took the lead on improving working conditions in department stores because unionization was difficult to achieve. Gender, social norms, and the workplace environment all contributed to the limited success of the labor movement in department stores. In Out to Work, Kessler-Harris observes that men and women often had different priorities within most national labor unions. Men were often more concerned with issues relating to their long-term association with a company or industry, such as their ability to influence management and production. Conversely, women were usually more concerned with their immediate working conditions relating to wages, hours, sanitation, and safety. These differing priorities led to an early split in the organized activities of

\footnotetext{
${ }^{307}$ Ibid, 88.

308 Ibid, 90.
} 
laboring men and women. ${ }^{309}$ Starting in the late 1860s, women began to organize their own trade unions, some of which sought to make alliances with male unions. Perhaps in an attempt to generate support with potential male allies, early female unions advocated for better working conditions, while at the same time identifying marriage and subsequent departure from the workforce as the goal of working women. ${ }^{310}$ Most male labor unions were opposed the inclusion of women and when women were permitted membership it was typically without voting rights. ${ }^{311}$

The public's preconceived notions of the labor movement also deterred female membership. In the latter part of the ninetieth century and early twentieth century, most unions were focused on reforming abuses in industrial workplaces. Most Americans associated "work" and "labor" with manual labor engaged in heavy manufacturing. ${ }^{312}$ During this time period, most women were employed in domestic labor and the home trades, therefore excluding them from the growing movement. Most unions rejected female members and rationalized that union gains would help women by working for the benefit of their husbands and fathers, hopefully keeping women out of the workforce entirely. ${ }^{313}$ In her book, Purchasing Power, Dana Frank details how Seattle AFL leaders debated the inclusion of women in workforce after WWI. Feminist unionists argued that women should be included in membership and the workforce regardless of whether her employment was by choice or out of need. On the other hand, opponents took the viewpoint of most unionists of the period, that women were an obstacle to union gains. ${ }^{314}$

\footnotetext{
${ }^{309}$ Kessler-Harris, Out to Work, 76.

${ }^{310}$ Ibid, 81.

${ }^{311}$ Flanagan, America Reformed, 50.

${ }^{312}$ Frank, Purchasing Power, 32.

${ }^{313}$ Wood, Freedom of the Streets, 32.

${ }^{314}$ Frank, Purchasing Power, 104.
} 
During the early twentieth century, women, along with minorities, were barred from membership with the exception of a small number of female-only unions with very limited association. ${ }^{315}$ In Seattle, the focus of Frank's study, department store clerks were not organized by the AFL or any other union. ${ }^{316}$

The outright exclusion of women in many unions and their segregation into female-only unions meant that the expanding power and influence of male-dominated unions in the early twentieth century did not necessarily translate into greater success for female labor unions. This created less incentive for female workers in department stores to unionize. Additionally, cultural expectations may have created self-imposed barriers to greater female participation in unions. Labor activist Leonora Barry observed that some women avoided union association because they believed their activities were better suited for men. They did not want to engage in the assertive behavior that union protests might require or feared that if they did, they would be judged un-favorably by society. ${ }^{317}$

Company paternalism may also have played a role in the lack of union support. In The Story of REO Joe, Lisa Fine explores the welfare programs at Lansing, Michigan's REO Motors, which included a clubhouse, hobby and Americanization classes, a mutual aid organization, and entertainment. ${ }^{318}$ These were all offerings similar to those provided by department stores, although in the case of REO, programs targeted male workers, while those in department stores targeted women. Welfare programs were attractive to businesses based on the belief that they instilled loyalty to the company and reduced

\footnotetext{
${ }^{315}$ Ibid, 21 and 9.

${ }^{316}$ Frank, Purchasing Power, 31.

${ }^{317}$ Vapnek, Breadwinners, 47.

${ }^{318}$ Fine, Story of REO, 43.
} 
turnover. $^{319}$ Nonetheless, REO employees made attempts to unionize which resulted in REO's suppression of union activities. Company managers and spies were on the lookout for any grounds to dismiss workers under suspicion of collaboration with unions. While there was some vocal opposition to anti-union policies between 1916 and 1918, by the end of that period, most workers seem to have accepted company paternalism and the idea of the REO "family.", 320 It is quite possible that a similar combination of union suppression by management and employee satisfaction with some aspects of welfare programs reduced unionization of the department store workforce.

The women's clubs that were widespread throughout the city of Chicago could also have discouraged union activity. In Freedom of the Streets, Sharon Wood explains that around the year 1870 , female workers were more likely to seek out women's clubs for support, rather than unions. Because they were controlled entirely by females, many women felt that they were a better medium to convey their concerns to the public. ${ }^{321}$ The clubs also provided services that would later be provided by or bargained for by unions. The clubs campaigned for better working hours \& conditions, provided educational opportunities, and advised women on career advancement. ${ }^{322}$

The working conditions and job prestige of some women further deterred participation in unions. Many occupations that might have been unionized, such as factory or retail work, were more desirable than domestic positions. This gave employers considerable leverage over striking women who could easily be replaced by other willing female workers. In the case of saleswomen, their low pay also made paying union dues a

\footnotetext{
319 Ibid, 44.

${ }^{320}$ Ibid, 58.

${ }^{321}$ Wood, Freedom of the Streets, 46-47.

322 Ibid, 77.
} 
hardship and long working hours made it difficult to draw attendance at meetings.

Furthermore, women lacked a public space outside of their workplaces to meet for union activities and gained little support from male unionists. ${ }^{323}$

Women being able to join the union may not have worked entirely in their benefit. Some feared that if union membership was extended to women, it could put their employment at risk if the union demanded gender equality in pay. Female laborers recognized that their lower wages gave them a market advantage and that if employers were forced to pay men and women equally that women would likely lose their job to men. ${ }^{324}$ Male union members were sensitive to the risk of low wage, female labor and often responded to female union members with hostility. They accused female workers of undermining the "family wage" ideal and providing cause for management to dismiss male workers. $^{325}$

Generally speaking, large trade unions seemed to have little concern about the working conditions in department stores and their impact on female employees. Frank cites a notable example of the intersection of department stores and the AFL that actually proved to be quite harmful to the workers of Seattle's Bon Marche store. The city's labor movement, growing increasingly frustrated with the ineffectiveness of strikes, sought to use a wide-scale boycott to generate national attention for labor concerns. That opportunity came in 1920 when department store Bon Marche began a building addition using non-union labor and then proceeded to deny its workers a previously promised half-day. ${ }^{326}$ As part of the campaign, union leaders tried to paint Bon Marche as an

\footnotetext{
${ }^{323}$ Vapnek, Breadwinners, 91.

${ }^{324}$ Wood, Freedom of the Streets, 33-34.

${ }^{325}$ Frank, Purchasing Power, 32.

${ }^{326}$ Ibid, 112.
} 
exploitive employer who forced their clerks to work in poor conditions and stifled all attempts at unionization. ${ }^{327}$ In fact, unionization had been attempted at Bon Marche the previous year. Seattle had a small retail clerk's union, but its membership was made up mostly of men who worked in small stores. The union attempted to organize women in the larger stores, but was fairly unsuccessful and abandoned further efforts. The male leadership of the union reasoned that the female clerks were uninterested in joining the union because many were either temporary workers or married women who worked only to supplement the family income. Realizing that these women were unlikely to join the union willingly, the retail clerk's union sought to force them into membership. They believed that if they supported the Bon Marche boycott that store management would force women to join the union in an attempt to bring the boycott to an end. ${ }^{328}$

As boycott wore on, it was Bon Marche's salesclerks who suffered some of the greatest hardships. The boycott had resulted in one-fourth of the workforce being laid-off or reduced to part-time. Union leaders celebrated this fact as evidence that the boycott was having an impact, but female clerks saw it as serious threat to their livelihood. ${ }^{329}$ Frank argues that the Bon Marche boycott highlights the deep gender divisions that existed in the labor movement. These issues would eventually impact the success of the boycott itself. The boycott was dependent on the participation of working women who served as the primary family shoppers in labor families, but the boycott was envisioned and directed by men who gave little consideration to how the boycott would impact the opposite gender. As a result, female enthusiasm for the boycott was understandably

\footnotetext{
${ }^{327}$ Ibid, 114.

${ }^{328}$ Ibid, 130.

${ }^{329} \mathrm{Ibid}, 129$.
} 
lukewarm. ${ }^{330}$ Over the course of 1921 , the boycott slowly died as individual unions abandoned it one by one. ${ }^{331}$

Boycotts were sometimes used against Chicago department stores, particularly in the 1890 s, but their causes were usually not a lack of unionization by department store employees. Boycotts were called for other issues such as the sale of goods produced with non-unionized labor ${ }^{332}$ and low wages for saleswomen. ${ }^{333}$ In a Chicago Tribune article covering a boycott attempt in 1897, organizers lamented the use of child labor in stores and called the treatment of department store employees "cruelty...enough to drive them to asylums." Interestingly, the organizers stopped short of calling for unionization and advocated reform instead, despite crediting union labor with improving working conditions. ${ }^{334}$ There seems to be little evidence that these boycotts were ever prolonged and wide-spread, much less successful at achieving their aims. In the case of the Bon Marche boycott, it is likely that Chicago department store clerks took notice of its progress and outcome because it garnered attention by the national press. The boycott highlights the fact that many saleswomen failed to see how unions might work in their best interest, a view that was likely strengthened by the negative impact that the AFL boycott had on many Bon Marche clerks.

In addition to these small boycotts, there were a number of attempts to unionize Chicago department store clerks, none of which were widely successful. In 1902, a group of smaller retail clerk unions formed an alliance as the Illinois Retail Clerk's Association. Demands of the group included seats for sales staff, "equal pay for equal

\footnotetext{
${ }^{330}$ Ibid, 126.

331 Ibid, 132

332 "Union Labor Vs. Anti-Big Store Men,” Chicago Daily Tribune, March 15, 1897, 5.

333 "Will Aid Major Swift," Chicago Daily Tribune, January, 24, 1897, 12.

334 “May Boycott Department Stores,” Chicago Daily Tribune, March, 27, 1897, 4.
} 
work, regardless of gender," and closing of stores on Sunday. Press coverage of their meetings in Springfield seems to indicate that they primarily sought these reforms through legal changes, perhaps indicating that stores were approached and unwilling to make these changes voluntarily. Spokesmen for the group called the current working conditions a "system of slavery" and expressed that a principle aim of the group would be to increase public awareness of long working hours and ill treatment by employers. Interestingly, there was some disagreement in the group about the use of the word "union" in reference to the organization. The apprehensiveness of some to use this term, substituting it instead with "association," might indicate that current public opinion viewed unions negatively and therefore would not be desirable. The hierarchy of the organization mimicked the male domination of males in store management. Just one of the union's twenty-one delegates for its inaugural convention was female and its executive board was entirely male. ${ }^{335}$ A little over a year later, the union staged a walkout of men's clothing stores on the north side of Chicago. The short strike was held in opposition to extended store hours in preparation for the Easter holiday. Store owners relented and agreed to maintain regular store hours in the future. The strikers and those speaking on their behalf were exclusively male, suggesting that relatively few women were being attracted to the union. It is quite possible that the union itself was encouraging this by appealing only to those clerks in niche stores, such as those targeted during the walkout. ${ }^{336}$

In reviewing coverage in the Chicago Tribune, it appears that strikes were rare events in department stores around the turn-of-the-century and strikes of the entire store

\footnotetext{
335 "Clerks Combine to Get Reforms" Chicago Daily Tribune, January, 8, 1902, 1

336 "Clerks Quit and Parade," Chicago Daily Tribune, April, 9, 1903, 2.
} 
workforce, from clerks to cashiers to deliverymen, were almost unheard of. In 1907, the staff of the Wieboldt department store on the northwest side of the city went on strike in the middle operations, protesting the refusal of store ownership to sign a union contract. The female organizers of the strike were arrested, although not charged, and the store continued operation with only its floor managers. This was the first time that such a large walkout occurred in a Chicago store, but it failed to inspire many similar incidents in the future. ${ }^{337}$ Based on press coverage during that time, it appears as though there were far fewer store strikes in the decades to follow. This is perhaps a consequence of the feminization of the department store sales staff, as women were less likely to join or be welcomed into labor unions.

Attempts at unionization sometimes intersected with the work for middle-class reformers, as was the case in an attempt at Chicago store unionization involving reformer Louise DeKoven Bowen. In 1913, she threw her support behind a newly formed clerk's union. When the organization held a meeting to recruit new members, Bowen expressed her frustration over the failures of reform organizations to secure a half-day off during the workweek and a living wage for all department store employees. She expressed optimism that union organization might be able to secure these benefits. There is evidence that there was significant opposition to this effort by the management of Chicago department stores. Women who attended the organization's public meeting spoke to the press about threats of firing from stores if they attended the labor meeting. Labor organizers were concerned enough that they offered to care for any worker who lost her job as a result of attendance. ${ }^{338}$ Almost a month later, the Retail Clerks'

\footnotetext{
337 “Woman Calls Strike,” Chicago Daily Tribune, February, 18, 1904, 5.

338 “Girl Clerks Hear Talk on Wages,” Chicago Daily Tribune, April 9, 1913, 6.
} 
Association had about 300 members out of a total department store workforce of 40,000.

At that time, the organization began to promote the idea of time and a half for overtime and double time for work on Sunday, but there is little evidence that large numbers of saleswomen were joining the union. ${ }^{339}$ The city's department stores apparently held a strong line, and Bowen later wrote that she suspected that the JPA lost a thousand dollar yearly donation given to them by the State Street stores because of her involvement in the organization. ${ }^{340}$ Despite these and other efforts, the organization of saleswomen did not considerably increase until the late 1930s and even then, only five percent of the workforce was unionized. ${ }^{341}$ At that time, the majority of clerks had obviously decided that the various barriers to union membership and the poor record of success in department store unionization did not make the potential benefits worth the risks, costs, and sacrifices involved.

\section{Success of Reformers}

While unionization efforts in department stores fell short, with help from working-class employees willing to share their work experiences with investigators, reformers were able to gain significant improvements for department store clerks. By appealing to public sympathy for the young, attractive saleswomen, reformers were able to pressure stores to gradually phase out their less-profitable evening hours. In 1902, the Chicago Tribune reported "substantial" progress in reducing evening hours throughout the city. Some stores closed as early as six-o'clock each day, while others closed early on specific nights of the week. ${ }^{342}$ Hours varied by establishment over the next several

\footnotetext{
339 “"Big Store Clerks Urged to Unite," Chicago Daily Tribune, April 28, 1913, 7.

${ }^{340}$ Bowen, Growing Up, 131.

${ }^{341}$ Benson, Counter Cultures, 269.

342 "Early Closing Progress." Chicago Daily Tribune, Feb 19, 1902, 12.
} 
decades, but most stores responded in some way to the call for reduced hours. These late hours had been the major factor in the long shifts worked by many early department store clerks. ${ }^{343}$ Reformers used their influence over middle-class buying power to push stores to provide saleswomen with seats and clean employee facilities. ${ }^{344}$ However, the actual benefit of these reforms might have been deceiving, as an 1899 Chicago Tribune article suggests. "The strength of public feeling on [seats for clerks] and the anxiety of merchants not to offend that feeling are indicated by the fact that the better stores in the city do provide seats... The trouble, however, lies in the fact that by an unwritten but well understood law these are for exhibition...," it read. ${ }^{345}$

More tangible were the results of wage reform. By the 1910s, reformers had succeeded in establishing minimum wages in many states (although Illinois was not one) and continued to pressure employers to pay a living wage. ${ }^{346}$ The idea of a living wage was the central theme of a 1913 Illinois State Senate committee hearing on department stores. Managers from all of Chicago's major stores were interviewed about the wages paid in their establishments and the reform minded sympathies of the state senators were made very clear. The businessmen were grilled over their failures to pay decent wages and the inequality of pay between men and women. The testimony of James Simpson, vice president of Marshall Field's, exhibited many similarities with the testimony provided by the other men during the hearing. In a heated exchange with Senator Tossey, he was asked if male and female clerks who performed their jobs equally well should be paid the same amount to which Simpson replied "Yes, surely." When Tossey then asked

\footnotetext{
${ }^{343}$ Benson, Counter Cultures, 196.

${ }^{344}$ Kessler-Harris, Out to Work, 166.

345 "Seats for Shop Girls." Chicago Daily Tribune, Jun 18, 1899, 32.

${ }^{346}$ Meyerowitz, Women Adrift, 65.
} 
him if the pay gap was therefore attributable to a greater number of female workers, Simpson stated "No, my impression is that they are not worth as much as men are." Throughout his testimony, Simpson was criticized for not knowing the statistical performance of his male versus female clerks, being unaware of the difficulties finding affordable housing, and his refusal to accept that low wages played a role in female prostitution. ${ }^{347}$ These hearings were widely covered in the Chicago press, which no doubt increased their influence with the public. While the legislature did not adopt the minimum wage for women that the committee sought, the positive news coverage of the committee likely encouraged stores to increase wages in order to generate good-will with customers.

\section{Impact of Reformers on Store Management}

While the public battles won by reformers on behalf of department stores clerks were fairly limited, their influence on the public-at-large was creating a cultural shift that would eventually extend into the business practices of the store. These changes were likely the result not just of the middle-class clientele that frequented the stores, but also the middle-class managers who took on most of the leadership positions. As Wiebe points out, middle-class workers were proud of their chosen profession and felt an obligation to advance the field. ${ }^{348}$ This was likely as true for managers as it was for doctors and lawyers. Consequently, middle-class managers brought their progressive ideals into with workplace with the intention of improving the business.

Progressive men and women had different priorities and viewpoints, however. Thus, the policies advocated by middle-class men were not always identical to those

\footnotetext{
${ }^{347}$ Report of the Senate Vice Committee, 1916, 719.

${ }^{348}$ Wiebe, Search for Order, 112.
} 
advocated by middle-class women. These differences are a central theme of Maureen Flanagan's work. She argues that women saw the community as an extension of the home and viewed reform as a way to bring social justice to the entire community. ${ }^{349}$ Female reform organizations were often more inclusive and democratic than men's because while upper and middle-class women often made up the leadership, the participation of women from a variety of socio-economic and ethnic backgrounds was valued. Flanagan characterizes these women as "doers" who would conduct investigations and generally petitioned for changes through government rather than private business. ${ }^{350}$ Conversely, she characterizes men as "talkers" who often hired out investigative work and tended to discuss their findings amongst other reformers. They were mistrustful of government, which they saw as corrupt, and would abandon reforms if that meant cooperating with flawed existing institutions. ${ }^{351}$ Generally speaking, men concerned themselves more with reforms that would benefit the economy and cleaning up government, while women focused more on quality of life issues. These distinctions are important because they help to explain why some of the ideas of female reformers were rejected by their male counterparts. If a proposed reform was likely to adversely impact department store profits, it would likely be rejected. Similarly, the plight of the female clerks might be dismissed by men as less important than the corruption of government and therefore not worthy of attention.

That is not to say that the ideas of female reformers were entirely ignored. While specific reforms might have been easier to reject, many middle-class men would have found it difficult to not sympathize with the protection of female workers in general.

\footnotetext{
${ }^{349}$ Flanagan, America Reformed, 88.

${ }^{350}$ Ibid, 91.

351 Ibid, 92.
} 
Over time, this movement may have softened many managers' approach to their female workforce. Also, specific appeals for reform could not be entirely ignored by men because the women making them were highly respectable. ${ }^{352}$ To criticize a woman like Louise DeKoven Bowen publically would have been akin to dismissing the values and ideas of their own wives. Of course this did occur, but middle-class men had to avoid doing so to such a great extent that they created offense. These conditions created small opportunities for gradual changes in store policy. Middle-class managers incorporated progressive ideals into the workplace not only because they personally held many of the paternalistic concerns of the JPA, but also because they had their own motivations for wanting clerks to adhere to middle-class values. An early example of this style of reform was the paternalistic policies adopted by many stores.

\section{Company Paternalism}

During the late nineteenth and early twentieth century, it was not unusual for companies to keep a close eye on their employees' behavior and personal lives. William Leach argues that department stores faced a serious "image problem" at the turn of the century. Backlash against exploitive corporations was on the rise and the large department stores were often lumped into this category, accused of treating their workers poorly. ${ }^{353}$ Pressure from a progressive-minded public was working to unite consumers of varied backgrounds and push for change en masse. Stores tried to convince the public that they were looking out for the best interests of their employees by implementing employee welfare programs. These programs also served to appease cultural concerns about women in public by making work more like domestic life. The programs claimed

\footnotetext{
${ }^{352}$ Wiebe, Search for Order, 175.

${ }^{353}$ Leach, Land of Desire, 116.
} 
to make the workers feel like part of the store "family" by providing hospital care, private schools, summer getaways, and the advice of a "matron." 354 Sarah Smith Malino suggests that companies were much more likely to implement welfare work programs if they employed a large number of women. Managers believed that they had a duty to protect women and they understood that their public image would be greatly damaged if they were perceived to be doing otherwise. Welfare work made it more difficult for the public to claim that department stores were exploiting their workforce. ${ }^{355}$

Scholars have some disagreement about the intent and consequences of welfare work programs. Malino argues the while welfare work programs could become paternalistic, they were generally well-intentioned and beneficial. Mutual aid organizations, employee outings, and recreational facilities were widely popular and drew large numbers of applicants to the department stores. ${ }^{356}$ Malino views these programs as mutually beneficial. Employers were able to gain goodwill and increased efficiency from their employees, while salespeople gained a sense of belonging and access to needed services. ${ }^{357}$ However, she acknowledges that while early programs were primarily benevolent, after 1905, welfare work increasingly tilted in favor of increasing sales performance and altering employee behavior. ${ }^{358}$

Susan Porter Benson on the other hand presents a more negative view of company welfare programs. She believes that the primary goal of these programs was to force working-class women to conform to middle-class values. Companies made few attempts to refine their hiring processes, assumed that all potential recruits were deficient in

\footnotetext{
${ }^{354}$ Ibid, 117-118.

355 Malino, "Faces Across the Counter," 63.

356 Ibid, 56.

${ }^{357}$ Ibid, 59-60.

358 Ibid, 72.
} 
refinement, and pressed them into the store welfare system as a remedy. ${ }^{359}$ Benson admits that many of the employee facilities rivaled those provided for customers, but that these also had the intent of altering seemingly un-acceptable employee behaviors. Managers assumed that if working-class women were surrounded by middle-class comforts, they would more easily conform to middle-class norms. They also assumed that such surroundings would create more pleasant employees and limit some of the bitter class-conflict between employees and customers. ${ }^{360}$ Access to discounts and charge accounts also put goods within reach of saleswomen in ways that were not available to other working-class women. ${ }^{361}$ While employees may have enjoyed some of the welfare benefits, they could also view them as an unfair influence into their private lives. Benson concludes that by 1920, many employees equated welfare work programs with paternalism. Companies continued to provide many of the program benefits, but their oversight became less obvious and many of the benefits became recognized as a normal part of store operations. $^{362}$

In this case perception was more important than reality. Desiring independence and respect in the workplace, women were rightfully critical of welfare programs when they were implemented essentially as a critique of workers. As the class-based messaging around these programs receded, however women understandably perceived the benefits, which largely remained the same, more favorably and as less offensive. Instead of viewing welfare work from the extremes of either Malino or Benson's point of

\footnotetext{
${ }^{359}$ Benson, Counter Cultures, 143.

${ }^{360}$ Ibid, 145 .

${ }^{361}$ Ibid, 234.

${ }^{362}$ Ibid, 146.
} 
view, I prefer to view welfare work programs as a flawed, but useful stepping stone toward better working conditions in the department store.

For department stores, another key function of welfare work was molding employees to serve the stores' target market: the middle-class. In order to keep labor costs low, stores continued to hire predominantly working-class women. Rather than allowing working-class women to exhibit their own social norms, department store managers believed that they could guide their sales staff into exhibiting behaviors of the middle-class. ${ }^{363}$ The dress codes discussed in the previous chapter were a good illustration of the effort. During the day to day operations of the store, men who were selected as members of management were given, not surprisingly, considerable control over their employees which could sometimes become extremely paternalistic. In a 1913 Marshall Field's policy paper explaining how workers should be developed within the company, managers were specifically instructed to help improve the "character" of their employees. ${ }^{364}$ This was to be done by setting a good example, but also through tactful instruction. Employees who would not exhibit "sound character" were deemed unfit for business. ${ }^{365}$ Managers presumed that this would make their employees more appealing to customers. Initially, these efforts were attempted without major organizational or managerial change to the store. For example, Marshall Field's tried to promote middleclass behaviors by outlining them in the "Book of Rules." Requirements included using prefixes on the names of fellow employees, refraining from personal grooming in the elevators, and chewing gum on the sales floor. ${ }^{366}$ These rather specific requirements

\footnotetext{
${ }^{363}$ Ibid, 142.

364 "Developing the Workers," 2.

${ }^{365}$ Ibid, 1.

366 "Book of Rules," 1911, 14, 15, and 16.
} 
were clearly meant to curb working-class behaviors and speech that management saw as undesirable.

Eventually, in an attempt to regulate employees beyond the restrictions laid out in the company "Book of Rules," Marshall Field's began to employ store "matrons," married women to watch over the girls working in the store, in association with the implementation of new, stricter store codes. Mrs. G. Hoinville was advertised to employees as a sounding board for their problems, both professional and personal, with whom they could visit at their leisure. According to a Chicago Tribune article about Mrs. Hoinville, while some saleswomen seemed glad to receive the matron's help, others were surprised to see her moving around the store and selecting girls to speak with. More often than not, she proceeded to rebuke them for a dress code violation, taking liberty to interpret the wording of the "Book of Rules." 367 She allowed girls only one "rat" in their hair (a popular technique of using a wad of human or horse hair underneath up-do styles to add volume $)^{368}$ and forced women to remove rings given to them by men who were not a husband or fiancé. Girls interviewed for the article said that "whatever she says goes" and that they were afraid to question her authority for fear of being dismissed. Marshall Field's executives, on the other hand, said that they were extremely pleased with the work of Mrs. Hoinville. Other department stores admitted that they had been "keeping supervision over their girls" for years. Significantly, the writer from the Tribune was complimentary of the program, calling it a "moral uplift" and seemed to believe that it had the long-term interests of the saleswomen in mind. ${ }^{369}$ This opinion was likely shared

\footnotetext{
367 “Trims Off Frills For Girls’ Uplift,” Chicago Daily Tribune, October, 19, 1909, 11.

${ }^{368}$ Victoria Sherrow, Encyclopedia of Hair: A Cultural History (Westport, CT: Greenwood Press, 2006), 387.

369 “Trims Off Frills," 11.
} 
by the Tribune's middle-class readership and similarly embraced by the city's reformers who were starting to turn their attention to department stores.

Selling was seen as different from other types of work because it required direct contact with customers. ${ }^{370}$ By the early twentieth century, consumer culture and the large department stores had grown to the extent that customers were completely detached from the production process. The salesperson became their only physical connection with the product between its conception and their consumption. ${ }^{371}$ Because salespeople were the face of the store and its products, the clerk's image became a priority for company executives. Managers were to make it clear that the house would be willing to help those in "trouble" outside of work if they made their problems known to management. Employee social groups were also encouraged, but only under the supervision of store executives. ${ }^{372}$ Even contemporaries viewed these practices as paternalistic, and stores were keen to address these concerns. Marshall Field's own worker's development policy stated that "paternalism" was not the policy of the store because individual rights were "sacred." By stating this explicitly, it is clear that the company wanted to avoid the negative publicity that might accompany this charge. However, Marshall Field's did include a caveat that the company had the right to be concerned with personal matters that could impact the business. Employees were supposed to always maintain moral associations in order to protect themselves and their fellow workers. ${ }^{373}$ This belief and the other policies laid out by the company gave the firm considerable leeway to meddle in the personal affairs of employees.

\footnotetext{
${ }^{370}$ Benson, Counter Cultures, 125

${ }^{371}$ Leach, Land of Desire, 150.

372 "Developing the Workers," 6.

${ }^{373}$ Ibid, 5.
} 
This arrangement was further complicated by the fact that most managers were men and most salespeople were women. ${ }^{374}$ Given the highly patriarchal society of the early twentieth century, these relatively loose policies could be abused. A middle-class, male manager in the context of the dominant social roles of the time likely felt justified in treating his working-class, female employees with a great deal of oversight and control. As the moral associations of female associates were more heavily scrutinized by society as a whole, the house may have seen this as justification to protect their business interests by interfering in a female employee's personal affairs. Given that stores employed managers specifically to monitor the social and physical behaviors of their employees, this was likely the case.

\section{Greater Autonomy for Clerks}

Despite the various reforms won by reformers and instituted by stores, female store clerks had relatively little autonomy. Predominant gender and class expectations limited their opportunities for advancement and self-support. Despite middle-class reformers' and unionized labor's attempts to improve working conditions for these women, many still lacked independence in the workplace. During the 1920s, however this began to change when the Victorian ideals that imposed limitations on women generations before gave way to the values of the generation of "new women." These women wanted personal autonomy and individual happiness, which they often sought by living independently and challenging prevailing moral attitudes. They also sought political influence through suffrage and work that they found fulfilling. ${ }^{375}$ When the middle-class began to accept these ideas, the changes also extended into the department

\footnotetext{
${ }^{374}$ Malino, "Faces Across the Counter," 212.

${ }^{375}$ Peiss, Cheap Amusements, 185
} 
store. Just as stores in the late nineteenth and early twentieth century had wanted to promote Victorian values in their stores to please middle-class customers, now they offered new opportunities to please this same demographic.

One of Chicago's largest department stores, Carson Pirie Scott, conducted a report in the 1920s that analyzed these changes within numerous aspects of store operations. Compiled in 1928 for internal consumption, the J.D. Houser Report consisted of dozens of customer surveys and the analysis of them. The major focus of the report was customer service, and the store planned to use the results of the surveys to help improve their employee training programs. The report concluded that Carson's employees were well versed in the "store system," that is the formal set of rules, departmentalization, and hierarchy that defined department stores of the time, but that they were poor salespeople. The saleswomen knew very little about current styles and the effectiveness of their sales techniques. ${ }^{376}$ Clerks were also poorly instructed in interaction with customers, which presented a considerable problem considering that the study indicated that one-third of customers' buying decisions were based on their interaction with the saleswoman. ${ }^{377}$ To make matters worse, what instruction was being given was delivered poorly. Managers were lecturing in a way that made clerks feel that they were being reprimanded and had little to contribute to store policy. ${ }^{378}$

In order to improve these issues, the Houser firm recommended that Carson's begin using the "conference" method of instruction. ${ }^{379}$ This would consist of members of management meeting with small groups of salespeople to discuss a particular area of

\footnotetext{
376 "Recommendations for Use of the Houser Survey," J.D. Houser Report, 1928, Box 1, "Carson, Pirie, Scott Records," Chicago Historical Society, Chicago, I.

${ }^{377}$ Ibid, 2 .

${ }^{378}$ Ibid, 3 .

${ }^{379}$ Ibid, 4.
} 
concern. The manager would introduce the topic for discussion and would have a few end goals in mind, but would allow the salespeople to drive most of the conversation. There would be a secretary present to record the discussion and distribute copies of notes to the attendees. This type of instruction was recommended because it was less boring than previously used techniques and allowed the saleswomen to feel like they were part of the process. ${ }^{380}$ Carson's took the advice of the report and implemented the conference method of instruction.

Store records hold the notes from several of these conferences, but they can be problematic. First of all, no record of dates or attendees was kept, making it difficult to determine the extent of the program and its participants. Second, while many ideas on a number of topics were recorded by secretaries, the speakers were not identified. The recorded notes could be stemming from a number of sources. It is possible that the ideas of saleswomen were being recorded, as the report suggested, but the responses to questions are very idealized. If indeed saleswomen were providing answers to conference questions, they could have been providing answers that management would have wanted to hear or they could have been genuine; it is impossible to tell which is the case. It is also possible that managers were answering their own questions and that the notes were intended to guide conference organizers. Lastly, the notes could be a compilation of the responses from both salespeople and managers. Secretaries could have been instructed to record only what the group or management determined to be the "best" answers. Nonetheless, these notes are valuable because they give us insight into ideas that the company valued regarding a variety of store issues at the end of the 1920s.

${ }^{380}$ Ibid, 3. 
According to the conference notes, saleswomen were to be given a good deal of autonomy when making sales. Salespeople were expected to be tactful, but otherwise were allowed to take their own sales approaches. They were allowed to "use their best judgment" when offering information about merchandise and making suggestions to the customer. Salespeople were not pressured to sell the most expensive merchandise and were given few hard and fast rules about how to determine what a customer wanted to spend. ${ }^{381}$ Selling was promoted as a profession, and clerks were encouraged to advance their education to improve their knowledge of style and fashion. Employees were encouraged to read fashion magazines, such as Vogue, and to take college courses in design and color. ${ }^{382}$ They believed that they had developed good taste from their work experience and research, but they also knew when to recognize that a woman may have better taste than themselves. Clerks were instructed to feel confident about their ability to make suitable, “fashion-right” suggestions for customers. ${ }^{383}$ A salesperson's personal dress was seen as a way to show off her skills in selecting fashionable attire. ${ }^{384}$ Unfortunately, while women had gained the trust of their employers in selling technique, they held little independence in tasks outside of selling. Sales people were barred from making adjustments and had to refer customer complaints to management. ${ }^{385}$

What is perhaps more telling than the gains made by saleswomen are the restrictions placed on their managers. Clerks were now viewed as semi-professionals, who would ideally make selling their career. Training was no longer seen as a way to

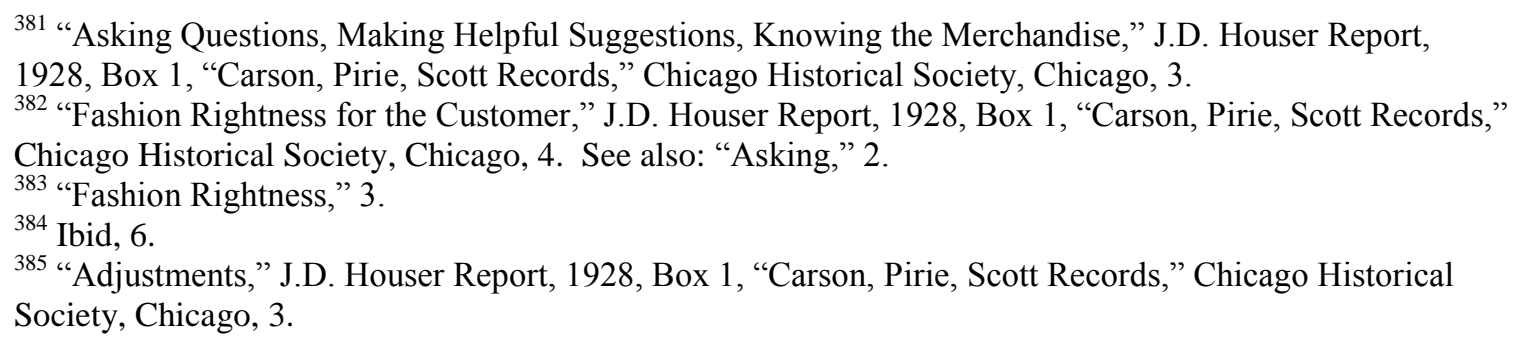


control salespeople, but as a way to create a better relationship between clerks and management and to allow the staff to contribute to the improvement of the store. Management recognized that salespeople were the only staff members that regularly came into contact with customers and therefore, they had valuable insight to offer. ${ }^{386}$ Managers had to take responsibility for the performance of their salespeople. If clerks failed to carry out instructions properly, it was considered the manager's fault for not providing effective instruction, not the clerk's for failing to grasp the material. ${ }^{387}$ Suggestions from saleswomen were supposed to be encouraged, and managers were instructed to receive them positively even if they would not be implemented. ${ }^{388}$ This was considered important for building up the self-confidence of salespeople. ${ }^{389}$ When instructions were given to staff, they were always to be worded as requests, not orders. ${ }^{390}$ It was the policy of Carson's to create a "spirit of approval," rather than a "spirit of fear" among its employees. ${ }^{391}$ When an employee made an error and a customer complained, the manager was always supposed to assume collective guilt for the mistake, not isolate the salesperson. ${ }^{392}$ The intent of these policies was that the salespeople were seen not only seen as an important part of store operations, but also as individuals with whom the future of the store was invested. It made sense for the company to have happy and independent salespeople who would help create a highly skilled workforce.

\footnotetext{
386 "Executive Practice for Buyers and Assistants on Salesmanship,” J.D. Houser Report, 1928, Box 1, "Carson, Pirie, Scott Records," Chicago Historical Society, Chicago, I.

387 "Principles of Leadership," J.D. Houser Report, 1928, Box 1, “Carson, Pirie, Scott Records,” Chicago Historical Society, Chicago, I.

388 "Executive Practice," 5.

389 “Principles of Leadership Building Morale,” J.D. Houser Report, 1928, Box 1, “Carson, Pirie, Scott Records," Chicago Historical Society, Chicago, I.

${ }^{390}$ Ibid, 3.

${ }^{391}$ Ibid, 4.

${ }^{392}$ Ibid, 6.
} 
While saleswomen were making many gains within the organizational structure of the department store, the J.D. Houser Report does show that the public still held on to some of their gender and class prejudices, but that a portion of the public was beginning to abandon them. One of the major benefits of the customer surveys that were used to compile the study is that data was taken from all four major Chicago department stores: Field's, Steven's, Mandel's, and Carson's. Many of the surveys specifically addressed clerks and provided an insight into public feeling about saleswomen. In one of these surveys, customers were asked what behaviors clerks exhibited that were done in the "wrong way." The items with the most frequent occurrence often related to perceived rudeness of the clerk, such as not showing a desire to help, forgetting to greet or make leave of the guest, or being inattentive. These behaviors were reported by $15-25 \%$ of customers. A smaller number of customers reported more class-specific concerns. Using slang (3\%), having poor taste in accessories (2\%), and generally lacking a pleasant appearance $(5 \%)$ were all reported. ${ }^{393}$ These numbers reveal that un-courteous behavior was a major concern for a large number of customers. Proper manners were an essential asset for department store clerks. But beyond personal courtesy, there were a small number of customers whose expectations more closely resembled earlier Victorian ideals. These customers wanted the clerks serving them to conform to the standards of middleclass dress and speech. However, given that a relatively small number of customers identify these concerns as very important, it can be assumed that store policies were adequately addressing customer concerns, that public sentiment was changing, or both.

393 “Table XXII," J.D. Houser Report, 1928, Box 1, “Carson, Pirie, Scott Records,” Chicago Historical Society, Chicago, I. 
The J.D. Houser report seems to indicate that public perception of clerks was changing and their standing within the department store was improving. This is evidenced by the books that were created to maintain standards for store management. As the work of saleswomen was professionalized, the women serving in these positions expected respectful treatment by their superiors. The Marshall Field's Floormen's Manual from 1922 laid out not only specific guidance for floor managers, but also defined their role in the business: "The Floorman...being at all times a monitor and guide, should be a living example of the spirit of the business at its best." Store executives were keenly aware that their department managers were the face of store management to their customers. Field's 1922 manual encouraged the floormen to always act in a way that they presumed the president of the company would conduct business, yet never overstep the boundaries of the duties delegated to them. ${ }^{394}$ Service to the customer was identified as the most important priority of floor managers. ${ }^{395}$ The main responsibility of floor managers was to physically walk the around the sales space monitoring sales staff and when necessary assisting with the service of customers. ${ }^{396}$ Floor managers were instructed to monitor the behavior of clerks to ensure that they were using proper speech, maintaining an acceptable posture, and avoiding indifference. ${ }^{397}$ Guidelines were also established for professional courtesy toward the sales staff. Managers were instructed to "be sympathetic and tactful" and "charitable in this thoughts and estimates" of store employees. ${ }^{398}$ The manual stressed the need to develop a cooperative relationship with employees by ensuring that they viewed managers as a

\footnotetext{
394 “Floormen's Manual," 5.

395 Ibid, 6.

396 Ibid, 18.

${ }^{397}$ Ibid, 18.

398 Ibid, 17.
} 
friend and were comfortable approaching them with any problems. Managers were encouraged to get to know their sales staff personally, show respect by calling their employees by their surnames, and avoid favoritism. ${ }^{399}$ Much of this advice seems to suggest that managers were being encouraged to be accommodating, but they are also encouraged not to appear "weak" and try to find a proper balance between friendly rapport and discipline. ${ }^{400}$ The guidelines and advice offered in this manual suggest that the spirit of cooperation and respect reflected in the J.D. Houser report was accepted by a number of department stores by the 1920s.

Other sources also support this conclusion, including a 1926 Chicago Tribune advice column titled "Opportunities for Girls in Business." This was a series dedicated to educating women about careers in which they might have a "fair chance of lucrative returns." The column reflects the view that women should show dedication to their work and strive for advancement until they chose to leave the workplace. "You may not be intending to work your entire life...But act as though you are during office hours. Be avid to learn instead of being constantly driven to it," the article advises. ${ }^{401}$ This is important because it displays the important shift occurring in women's expectations of working life no longer being about doing a job, but instead about maintaining a career. It chastised women who held on to older ideas about women's employment, saying "the lackadaisical girl...who regards her job as makeshift until matrimony comes along...is making it hard for other girls to get a chance to show what they can do." It stressed the need for education, pressing girls to finish high school and move on to further training in

\footnotetext{
${ }^{399}$ Ibid, 19.

${ }^{400}$ Ibid, 19.

${ }^{401}$ Georgia Bayne, "Opportunities for Girls in Business," Chicago Daily Tribune, September 12, 1926, C3.
} 
their chosen field. ${ }^{402}$ The article goes on to review job sectors where women might use their education, advance in the organization, and generally do well. Opportunities within department stores were included in this selection.

The Tribune column identified the department store as a "fertile field for girls who wish to enter business." Clerking was discussed as an entry-level position, but was described positively. The article stressed the opportunities for pay increases over time and advancement to the position of buyer for women who start out as clerks. Positions available in the advertising, employment, and research departments were also suggested. The same column also provided a description of opportunities in real estate, detective work, government service, file clerking, and insurance sales. ${ }^{403}$ While many of these positions would have held higher pay and greater prestige than that of a department store saleswoman, the fact that they were included in the same advice column is significant. This implies that the writers felt that all of these jobs were suitable to the middle-class, or at least the aspiring middle-class, readers of the Chicago Tribune. Similar advice would have been unlikely decades earlier when many middle-class parents would have cringed at the thought of their daughter working as a clerk. The column illustrates that working conditions and opportunities in the department store had improved to the point that young, middle-class women saw this work as a viable career option.

One of the driving factors behind this change would have been the changing views of women's role in society as a whole. By the 1920s the concept of the "new woman" had expanded. Smith-Rosenberg describes the "new woman" in two distinct generations. The first were frequently outspoken feminists who challenged traditional

\footnotetext{
402 Bayne, "Opportunities for Girls," C3.

403 Ibid, C3.
} 
definitions of gender, but often maintained older moral values. This generation was deeply concerned with issues of social justice and was active in the reform movement. The second generation of "new women" placed a greater emphasis on individual satisfaction and "the flamboyant presentation of self." They frequently challenged sexual mores and pushed for equality with men. ${ }^{404}$

The prevailing stereotype of the liberated woman of the 1920s however has been challenged by historian Lynn Dumenil in her book, Modern Temper. She acknowledges that women were making significant gains, but emphasizes that they were still far from achieving full autonomy and equality. ${ }^{405}$ This was particularly true within the workplace. While the percentage of women in the workforce rose from 20.6 to 25.3 percent in the first three decades of the twentieth century, the overwhelming majority of women were still working in jobs known as “women's work," such as saleswomen. These women were still young, single, and if they were living alone, likely barely able to support themselves. $^{406}$

The opportunities available to racial and ethnic minorities were still severely limited, but white, native-born women were experiencing greater opportunities in whitecollar work. ${ }^{407}$ At the same time, middle- class women were working outside the home in greater numbers than ever before. ${ }^{408}$ While many middle-class women chose to work in white-collar jobs that required training beyond high school, some middle-class women began accepting positions as store clerks. Some of these women wanted the opportunity

\footnotetext{
${ }^{404}$ Smith-Rosenberg, Disorderly Conduct, 177.

${ }^{405}$ Lynn Dumenil, The Modern Temper: American Culture and Society in the 1920s (New York: Hill and Wang, 1995), 98.

${ }^{406}$ Ibid, 112-113

${ }^{407}$ Ibid, 114.

${ }^{408}$ Benson, Counter Cultures, 213.
} 
to work in fashion. Others found the minimal entry requirements for a saleswoman appealing and preferred this position over domestic or factory work which they perceived as too demeaning. ${ }^{409}$

The presence of these middle-class women in the department store workforce may have encouraged management and the public to have a higher opinion of saleswomen and extend to them greater opportunities to contribute to the operations of the store. The training programs that became widespread in the 1920 s, as exemplified by the J. D. Houser Report, were likely partially a response to the influx of middle-class saleswomen. This professionalization of selling had the potential to make salesmanship more satisfying for middle-class women entering the field or for working-class women who were acquiring increasing levels of education. Some stores developed training programs to help groom saleswomen for promotion independent of or sometimes as a complement to a college education. ${ }^{410}$ Some of these store-managed programs may have contributed to the improved working conditions for saleswomen, but of equal or greater importance were the expectations of the saleswomen themselves. They had embraced their status as "new women" and expected that this autonomy would extend into the workplace. Especially for white, native-born women, the 1920s had opened up more employment opportunities. ${ }^{411}$ If work as a saleswoman did not satisfy an educated, young woman, she could seek employment elsewhere. Consequently, while department stores were still highly gendered and class-conscious workplaces, saleswomen of the 1920s enjoyed better working conditions than her counterparts a generation earlier.

\footnotetext{
${ }^{409}$ Dumenil, Modern Temper, 114.

${ }^{410}$ Benson, Counter Cultures, 165.

${ }^{411}$ Dumenil, Modern Temper, 114.
} 


\section{CHAPTER V \\ CONCLUSION}

In 1926, the Chicago Tribune declared that "[the] modern department store offers a fertile field to girls who wish to enter business. ${ }^{\circledR 412}$ Four decades earlier this statement would have seemed nearly unimaginable. At that time, the "field" scarcely existed. The new consumer culture that propelled female workers into the retail world was in its infancy and department stores were still a developing concept. But as the consumer culture grew, so did opportunities for saleswomen. By the turn-of-the-century, women made up a solid majority of department store clerks, but they were struggling to establish a career that provided for their economic needs, while at the same time offering them opportunities for advancement. These young women were often unsatisfied, but their frustrations were shared. Middle-class reformers recognized the importance of department stores as a symbol of the culture and values of the time period and they worked hard on behalf of reforms that could improve the lives of clerks. Saleswomen also took matters into their own hands, by experimenting with unionization and pushing back against policies that they viewed as paternalistic. Fortunately, views amongst the general public were shifting also.

The 1920s ushered in a generation of young women who held the belief that they were entitled to basic fairness and the opportunity for increased equality in the workplace. The department store began to reflect these values by improving working

${ }^{412}$ Bayne, "Opportunities for Girls," C3. 
conditions and allowing for greater autonomy in the workplace. The combined efforts of saleswomen, store management, and middle-class reformers were essential in this change. Some historians have viewed the efforts of reformers and reform-minded managers as domineering and paternalistic, since they appear more concerned with social control and morality than the welfare of working-women. But I do not believe that saleswomen would have seen marked improvements in their working conditions without the assistance of these groups. Nor should the efforts of the saleswomen themselves be discounted. Despite considerable risk to their jobs, many clerks took action to improve their standing in the workplace. Undoubtedly, the subtle pressure that they placed on management for increased autonomy and the skill at which they performed their duties went just as far toward achieving the respect in the workplace that they sought.

While much ground has been covered in the scholarship on department stores and saleswomen, there is still room for deeper exploration. Likely due to the dramatic changes occurring during the decade, most historians have restricted their scope to 1920 or 1930. It would be interesting to see if studies extending into the 1940s or 1950s would continue to see gradual improvement in working conditions. Given that the Progressive reform movement declined during the 1920s, a study extending further out might also provide insight into other groups that may have moved in to take their place in the attempts to better the workplace environment in department stores. There has also been limited attention given to racial and ethnic minorities in most existing scholarship. While these groups were generally barred from employment as clerks in the large downtown stores, they were employed in smaller stores around the city and in their own 
neighborhoods. An exploration of their work experiences would be a great complement to the stories of mostly white, native-born women in the flagship stores. 


\section{REFERENCES}

"A Day with a Wage Earner no.9 The Department Store Superintendent." Chicago Daily Tribune (1872-1922), Jul 24, 1901, 4.

Abelson, Elaine S. When Ladies Go a-Thieving: Middle-Class Shoplifters in the Victorian Department Store. New York: Oxford University Press, 1989.

Addams, Jane. A New Conscience and an Ancient Evil. New York: The Macmillan Company, 1912.

Bayne, Georgia. "Opportunities for Girls in Business." Chicago Daily Tribune (19231963), Sep 12, 1926, E2.

Benson, Susan Porter. Counter Cultures: Saleswomen, Managers, and Customers in American Department Stores, 1890-1940. Urbana: University of Illinois Press, 1986.

"Big Store Clerks Urged to Unite." Chicago Daily Tribune (1872-1922), Apr 28, 1913, 7.

Bowen, Louise de Koven. "The Department Store Girl: Based upon Interviews with 200 Girls." Pamphlet, 1911.

—. Growing Up with a City. Urbana: University of Illinois Press, 2002;1926.

Carson, Pirie, Scott Records., J. D. Houser Report. Chicago Historical Society, Chicago.

Chudacoff, Howard P. The Age of the Bachelor: Creating an American Subculture. Princeton, N.J.: Princeton University Press, 1999.

Ciani, Kyle E. "Hidden Laborers: Female Day Workers in Detroit, 1870-1920." Journal of the Gilded Age and Progressive Era 4, no. 1 (January 2005), 23-51.

"Classify Shoppers by the Day and Hour." Chicago Daily Tribune (1872-1922), Jun 5, 1904, 23.

Clement, Elizabeth Alice. Love for Sale: Courting, Treating, and Prostitution in New York City, 1900-1945. Chapel Hill: University of North Carolina Press, 2006.

"Clerks Combine to Get Reforms." Chicago Daily Tribune (1872-1922), Jan 8, 1902, 1.

"Clerks Quit and Parade." Chicago Daily Tribune (1872-1922), Apr 9, 1903, 2. 
Deutsch, Sarah. Women and the City: Gender, Space, and Power in Boston, 1870-1940. New York: Oxford University Press, 2000.

"Display Ad 5 -- no Title." Chicago Daily Tribune (1872-1922), Dec 12, 1880, 9.

"Display Ad 7 -- no Title." Chicago Daily Tribune (1872-1922), Sep 20, 1916, 9.

"Display Ad 8 -- no Title." Chicago Daily Tribune (1872-1922), Oct 15, 1910, 18.

"Display Ad 15 -- no Title." Chicago Daily Tribune (1872-1922), Dec 19, 1910, 22.

"Display Ad 86 -- no Title." Chicago Daily Tribune (1872-1922), Oct 10, 1920, E12.

Dumenil, Lynn. The Modern Temper: American Culture and Society in the 1920s. 1st ed. New York: Hill and Wang, 1995.

"Early Closing Progress." Chicago Daily Tribune (1872-1922), Feb 19, 1902, 12.

Enstad, Nan. Ladies of Labor, Girls of Adventure: Working Women, Popular Culture, and Labor Politics at the Turn of the Twentieth Century. New York: Columbia University Press, 1999.

Field, Hollis W. "Women Filling Up Counters; Sell More Goods than Men." Chicago Daily Tribune (1872-1922), Jan 19, 1908, E5.

Fields, Jill. An Intimate Affair: Women, Lingerie, and Sexuality. Berkeley: University of California Press, 2007.

Fine, Lisa M. The Souls of the Skyscraper: Female Clerical Workers in Chicago, 18701930. Philadelphia: Temple University Press, 1990.

- The Story of Reo Joe: Work, Kin, and Community in Autotown, U.S.A. Critical Perspectives on the Past. Philadelphia, PA: Temple University Press, 2004.

Flanagan, Maureen A. America Reformed: Progressives and Progressivisms, 1890s1920s. New York: Oxford University Press, 2007.

- Seeing with their Hearts: Chicago Women and the Vision of the Good City, 1871-1933. Princeton, N.J.: Princeton University Press, 2002.

Fox, Richard Wightman and T. J. Jackson Lears. The Culture of Consumption : Critical Essays in American History, 1880-1980 New York: Pantheon Books; 1st ed, 1983.

Frank, Dana. Purchasing Power: Consumer Organizing, Gender, and the Seattle Labor Movement, 1919-1929. New York: Cambridge University Press, 1994. 
"Girl Clerks Hear Talks on Wages." Chicago Daily Tribune (1872-1922), Apr 9, 1913, 6.

"How to Keep Your Daughter from Becoming a Saleslady." Chicago Daily Tribune (1872-1922), Nov 10, 1907, B1.

Kessler-Harris, Alice. Out to Work: A History of Wage-Earning Women in the United States. 20th anniversary ed. Oxford, Eng.; New York: Oxford University Press, 2003.

King, Mary. "For and by Business Girls." Chicago Daily Tribune (1872-1922), Sep 17, 1916, D6.

Leach, William. Land of Desire: Merchants, Power, and the Rise of a New American Culture. 1st ed. New York: Pantheon Books, 1993.

Lears, T. J. Jackson. Rebirth of a Nation: The Making of Modern America, 1877-1920. 1st ed. New York: HarperCollins, 2009.

Malino, Sarah Smith. "Faces Across the Counter: A Social History of Female Department Store Employees, 1870-1920." Ph.D., Columbia University, 1982.

Marshall Field and Company Records. Chicago Historical Society, Chicago.

"May Boycott Department Stores." Chicago Daily Tribune (1872-1922), Mar 27, 1897, 4.

McGerr, Michael E. A Fierce Discontent: The Rise and Fall of the Progressive Movement in America, 1870-1920. New York: Free Press, 2003.

Meyerowitz, Joanne J. Women Adrift: Independent Wage Earners in Chicago, 18801930. Chicago: University of Chicago Press, 1988.

Miler, Judy K. "Hidden within: Women's Managerial Role in the Rise and Development of Two Major U.S. Department Stores, 1870-1920." Ph.D., University of Tennessee, Knoxville, 1990.

Muncy, Robyn. Creating a Female Dominion in American Reform, 1890-1935. New York: Oxford University Press, 1991.

Odem, Mary E. Delinquent Daughters: Protecting and Policing Adolescent Female Sexuality in the United States, 1885-1920. Chapel Hill: University of North Carolina Press, 1995.

Peiss, Kathy Lee. Cheap Amusements: Working Women and Leisure in Turn-of-theCentury New York. Philadelphia: Temple University Press, 1986. 
Rabinovitz, Lauren. For the Love of Pleasure: Women, Movies, and Culture in Turn-ofthe-Century Chicago. New Brunswick, N.J.: Rutgers University Press, 1998.

Raymond. "Saleswomen are Well Educated." Chicago Daily Tribune (1872-1922), Jul 5, 1907,1 .

Report of the Senate Vice Committee Created Under the Authority of 48th General Assembly. Chicago: State of Illinois, 1916.

Rosenzweig, Roy. Eight Hours for what we Will: Workers and Leisure in an Industrial City, 1870-1920. New York: Cambridge University Press, 1983.

Schultz, Rima Lunin, Adele Hast, and Paul Avrich Collection. Women Building Chicago 1790-1990: A Biographical Dictionary. Bloomington: Indiana University Press, 2001.

"Seats for Shop Girls." Chicago Daily Tribune (1872-1922), Jun 18, 1899, 32.

Sherrow, Victoria. Encyclopedia of Hair: A Cultural History. Westport, Conn.: Greenwood Press, 2006.

"Shopgirl Fights Minimum Wages." Chicago Daily Tribune (1872-1922), Jan 10, 1915, 1.

Smith-Rosenberg, Carroll. Disorderly Conduct: Visions of Gender in Victorian America. 1st ed. New York: A.A. Knopf, 1985.

"Stores Robbed by Cupid." Chicago Daily Tribune (1872-1922), Dec 2, 1901, 1.

Strange, Carolyn. Toronto's Girl Problem: The Perils and Pleasures of the City, 18801930. Toronto: University of Toronto Press, 1995.

Trachtenberg, Alan. The Incorporation of America: Culture and Society in the Gilded Age. 25th anniversary ed. New York: Hill and Wang, 2007; 1982.

"Trims Off Frills for Girls' Uplift." Chicago Daily Tribune (1872-1922), Oct 19, 1909, 11.

"Union Labor Vs. Anti-Big Store Men." Chicago Daily Tribune (1872-1922), Mar 15, $1897,5$.

Vapnek, Lara. Breadwinners: Working Women and Economic Independence, 1865-1920. Urbana: University of Illinois Press, 2009.

Veblen, Thorstein. The Theory of the Leisure Class. New York: Macmillan, 1902. 
Wiebe, Robert H. The Search for Order, 1877-1920. The Making of America. 1st ed. New York: Hill and Wang, 1967.

Wolcott, Victoria W. Remaking Respectability: African American Women in Interwar Detroit. Chapel Hill: University of North Carolina Press, 2001.

Woloch, Nancy. Women and the American Experience. 4th ed. Boston, Mass.: McGrawHill, 2006.

Wood, Sharon E. The Freedom of the Streets: Work, Citizenship, and Sexuality in a Gilded Age City. Chapel Hill: University of North Carolina Press, 2005.

"Woman Calls a Strike." Chicago Daily Tribune (1872-1922), Feb 18, 1904, 5. 